\title{
Optimal rice land protection in a command economy
}

\section{Crawford School Working Paper 1707 August/2017}

\author{
Long Chu, Hoa-Thi-Minh Nguyen, Tom Kompas, Khoi Dang, and Trinh Bui
}

\begin{abstract}
Agricultural land protection (ALP) is a standard policy response to growing food security concerns driven by urbanisation, population growth and uncertainty over climate change. However, if not supported by rigorous analysis, at least in terms of the correct scale of protection, ALP may result in a misallocation of resources, hampering economic efficiency and prosperity. Examining rice land policy in Vietnam, this paper aims to determine the optimal level of rice land protected against other crops and evaluates the impact of adopting the optimal policy. With a stochastic optimization model built on top of a computable general equilibrium framework and microsimulation techniques, applied to Vietnam's social accounting matrix and household survey data, we find that converting part of protected rice land into other crops enhances economic efficiency. While the efficiency gain could amount to billions of dollars, income inequality only improves slightly. Overall, the policy is relatively pro-rich, implying a trade-off between poverty reduction and economic efficiency for Vietnam, making some households in already poor areas worse off. Though calibrated to a specific case, our approach can be applied in land-use planning generally, highlighting the relevant tradeoffs and the search for needed optimal land-use policies.
\end{abstract}

JEL Codes: Q18; Q15; Q24

Keywords: farmland preservation; general equilibrium; inequality; rice; Vietnam; welfare 


\section{Suggested Citation:}

Chu, L., HTM. Nguyen, T. Kompas, K. Dang, and T. Bui, 2017, Optimal rice land protection in a command economy, Crawford School Working Paper 1707, August 2017. Crawford School of Public Policy, The Australian National University.

\section{Address for Correspondence:}

Name: Professor Tom Kompas

Address: Crawford School of Public Policy, Crawford Building \#132, Lennox Crossing, Australian National University, ACT, 2601, Australia

Tel: +61 0261250577

Email: tom.kompas@anu.edu.au

Crawford School of Public Policy

College of Asia and the Pacific

The Australian National University

Canberra ACT 0200 Australia

www.anu.edu.au

The Crawford School of Public Policy is the Australian National University's public policy school, serving and influencing Australia, Asia and the Pacific through advanced policy research, graduate and executive education, and policy impact. 


\title{
Optimal rice land protection in a command economy
}

\author{
Long $\mathrm{Chu}^{\mathrm{a}}$, Hoa Thi Minh Nguyen ${ }^{\mathrm{a}}$, Tom Kompas ${ }^{\mathrm{a}, \mathrm{b}, *}$, Khoi Dang ${ }^{\mathrm{c}}$, Trinh Bui ${ }^{\mathrm{d}}$ \\ ${ }^{a}$ Crawford School of Public Policy, Crawford Building (132), Lennox Crossing, Australian National \\ University, ACT, 2601, Australia \\ ${ }^{b}$ Centre of Excellence for Biosecurity Risk Analysis, University of Melbourne, VIC, 3010, Australia \\ ${ }^{c}$ Center of Agricultural Policy, Institute of Policy and Strategy for Agriculture and Rural Development, 16 \\ Thuy Khue, Hanoi, Vietnam \\ ${ }^{d}$ Association of Regional Econometrics and Environmental Studies, Japan
}

\begin{abstract}
Agricultural land protection (ALP) is a standard policy response to growing food security concerns driven by urbanisation, population growth and uncertainty over climate change. However, if not supported by rigorous analysis, at least in terms of the correct scale of protection, ALP may result in a misallocation of resources, hampering economic efficiency and prosperity. Examining rice land policy in Vietnam, this paper aims to determine the optimal level of rice land protected against other crops and evaluates the impact of adopting the optimal policy. With a stochastic optimization model built on top of a computable general equilibrium framework and microsimulation techniques, applied to Vietnam's social accounting matrix and household survey data, we find that converting part of protected rice land into other crops enhances economic efficiency. While the efficiency gain could amount to billions of dollars, income inequality only improves slightly. Overall, the policy is relatively pro-rich, implying a trade-off between poverty reduction and economic efficiency for Vietnam, making some households in already poor areas worse off. Though calibrated to a specific case, our approach can be applied in land-use planning generally, highlighting the relevant tradeoffs and the search for needed optimal land-use policies.
\end{abstract}

Keywords: farmland preservation, general equilibrium, inequality, rice, Vietnam, welfare.

\footnotetext{
${ }^{*}$ Corresponding author: Tom Kompas, Crawford School of Public Policy, Australian National University, ACT, 2601, Australia. Phone: +61 026125 0577, email: tom.kompas@anu.edu.au

Email addresses: long.chu@anu.edu.au (Long Chu), hoa.nguyen@anu.edu.au (Hoa Thi Minh Nguyen), tom.kompas@anu.edu.au (Tom Kompas), khoi.dang@cap.gov.vn (Khoi Dang), buitrinhcan@gmail.com (Trinh Bui)
}

August 22, 2017 


\section{Introduction}

Agricultural land protection (ALP) is applied in many countries in their transition to more modern and industrialised economies. Rapid urbanisation, being inevitable and often necessary for economic development, affects the supply of prime agricultural land (e.g. Firman, 2000; Ho and Lin, 2004; Deng et al., 2015). Furthermore, rapid population growth, slow improvements in agricultural productivity and reductions in land suitable for agricultural cultivation due to the effects of climate change, all lead to serious concerns over food security (Fazal, 2001; Montgomery et al., 2003; Schmidhuber and Tubiello, 2007; Godfray et al., 2010). In this context, interventions by governments to protect agricultural land are often recommended to cope with the decrease in farmland and to guard against uncertainties in food supply (Azadi et al., 2011). They are typically justified in mitigating the socio-economic impacts of farmland losses, affecting rural households in particular, and in addressing multiple land market imperfections that prevent the efficient consolidation of farmland in the first place, especially in transitional economies (Nelson, 1990; Deininger et al., 2003).

ALP is inherently contextual and highly complex (Deininger et al., 2003). These characteristics are due to the significant variation in the level of development, along with differences in political systems, institutions, history and the extent of agricultural land scarcity in each country (Alterman, 1997; Ding, 2003; Bengston et al., 2004; Tan et al., 2009; Lichtenberg and Ding, 2008). In spite of this diversity, ALP policies to date tend to share a common attribute, namely the lack of hard evidence to help designate the optimal amount of farmland to be protected.

We focus on a special case of farmland protected for a particular crop against all other crops. This policy is not uncommon in many developing countries where a crop is of high economic and political significance, so that protecting its land-use is an familiar option for policy-makers. Examples are the protection of rice land in Asian countries (e.g. Markussen et al., 2011; Fujita et al., 2009) or cotton land in Central Asia (Halimova, 2007). Research on this policy has been mostly restricted to its impact on welfare or efficiency (e.g. Kutzman, 2016; Giesecke et al., 2013; Markussen et al., 2011; Martini and Kimura, 2009; Fujita 
et al., 2009; Kurosaki, 2008; Halimova, 2007; Nielsen, 2003; Brandt et al., 2002). Meanwhile, increasingly more studies measure how much farmland has been lost (e.g. Pandey and Seto, 2015; Gibson et al., 2015). However, few studies provide guidance on how much land should be protected to aid the decision-making process, not only in this special case, but also in general.

Nevertheless, the challenges to answering the question of "how much?" farmland should be protected are worth noting. First, farmland protection often has multiple goals from a policy making perspective, thus complicating an optimization exercise. Second, land allocation has an economy-wide impact, and therefore, should be analyzed using a general equilibrium framework nested within an optimization model. As a result, the computationally exercise is demanding. Finally, it is also an exercise that demands a good deal of data, since, at the least, it requires information on returns to alternative land uses which is generally not available.

In this study, we attempt to determine how much farmland for a particular crop should be protected and thus not used for other crops. To do so, we use a stochastic optimization model built on top of a general equilibrium (GE) framework. While our model is applied to this special case, it can be utilized in a broader context where farmland is protected from all other purposes including non-agricultural ones. Regarding policy objectives, we consider economic efficiency, measured by changes in Gross Domestic Product (GDP). Due to practical constraints in data and computational capacity, our GE framework is basic. We complement our aggregate analysis using a micro-simulation on household data to measure equality using the Gini index, and provide insights on distributional impacts of the best policy option on households in various regions and of different wealth classes.

We choose Vietnam as a case study for a few reasons. First, Vietnam is a key rice exporter in the world rice market, which itself is thin and vulnerable to production shocks by key players (Timmer, 2010; Slayton, 2009; David and Huang, 1996). As a result, a stable and predictable rice land policy in Vietnam, supported by careful analysis, sould reduce uncertainty over the rice supplies; while an arbitrarily set scale of rice land protection and 
frequent adjustments in the policy, together with a politically-driven industrial structure here (Fulton and Reynolds, 2015; Markussen and Tarp, 2014), will likely add to volatility in world rice prices and supplies. Second, for Vietnam itself, rice-related policies have widespread impacts on household living standards, given that rice remains the main staple, especially for the poor, and that rice production involves roughly two-thirds of rural households $(\mathrm{Vu}$, 2008). Finally, like many developing countries, Vietnam is currently under enormous pressure to use land more efficiently to enhance economic growth, while feeding its population, whose diet is shifting towards meat as their income increases (Kompas et al., 2015). Under these circumstances, a recent government decision to protect 7.0 million hectares of planted rice land, raises concerns over the arbitrary nature of this decision and what it is achieving.

Our results are generated using Vietnam's social accounting matrix table (SAM) for 2011 and the Vietnam household living standard survey (VHLSS) data for 2010. We find that converting some protected rice land into other crops enhances both economic efficiency and overall income-based equality. However, detailed distributional impacts of the policy on both household income and consumption indicate that it is actually pro-rich, thus implying a trade-off between poverty reduction and economic growth for Vietnam; a country on course for transforming and modernising its rural economy to increase rural incomes and enhance economic development.

\section{Background}

In this section, we provide some background on the rice land protection in the world which is followed by a description of the situation and policy context in Vietnam.

\subsection{Rice land protection in the world}

Protection of rice land is important for world food security. Rice is the most important staple for poor people in the world and it is grown where most of them live, and thus an integral part of any measures to address world hunger and poverty (GRiSP, 2013). Being primarily produced and consumed in Asia, rice is of vital political and socio-economic importance in this region (GRiSP, 2013). For this reason, it is not uncommon to observe 
government intervening in rice markets and distorting rice production, marketing and exports, making the world rice market and its relative control by a handful of countries in this part of the world more vulnerable to shocks (Timmer, 2010; David and Huang, 1996).

While Asian countries share the same desire to protect rice land, they apply different protection measures and achieve or bear varying levels of success or cost. For example, Japan is highly successful in maintaining rice land by providing substantial subsidies to farmers, but at the expense of competitiveness in the rice sector, and thus has to shoulder a high fiscal burden (Martini and Kimura, 2009). Indonesia, on the other hand, struggles to control land conversion due to rapid urbanization and the lack of effective counter-measures (Firman, 2000). Meanwhile, China succeeds in protecting agricultural land in quantity but fails in quality (Mao et al., 2012; Kong, 2014). At the end of the spectrum of strict rice land protection, Vietnam and Myanmar both have land designated for rice where farmers have no choice but to plant rice (Fujita et al., 2009; Markussen et al., 2011). Existing studies suggest that this policy results in inefficiency and hinders the poverty reduction process, especially in Vietnam (Markussen et al., 2011; Giesecke et al., 2013).

\subsection{Rice and rice land protection in Vietnam}

Rice is an integral part of Vietnamese culture and history, often referred to as a 'rice civilization' in the past. It was used by the current ruling Communist Party to gain broadbased support against the French colonists in a war that led to the independence of Vietnam in 1945 (Kerkvliet, 1997). For its role in the culture and history of Vietnam, golden rice paddy panicles are part of Vietnam's national coat of arms, and in the symbols of all legislative, executive and judicial organizations.

The importance of rice in Vietnam is also driven by its role in economic development. At the household level, rice represents $60 \%$ and $25 \%$ of household calorie consumption and food expenditure of an average household, and $70 \%$ and $40 \%$ of poor households, respectively $(\mathrm{Vu}$, 2008). Meanwhile, rice production involves about $66 \%$ of rural households and $77 \%$ of poor households (Ha et al., 2015). At the country level, rice export revenues contribute about $3 \%$ of total GDP (General Statistic Office, 2011), and used to be one of the most significant 
contributors to Vietnam's foreign reserves, when the country shifted, with agricultural and market reforms, from being a net food importer to now a key rice exporter in the world. This shift is often regarded as a remarkably successful transition story, lifting many Vietnamese people out of poverty, and certainly so compared to the prior period of agricultural collectivisation applied for more than three decades in the North and ten years in the South (Kompas et al., 2012).

Collectivised agriculture put Vietnam in an economic crisis (Pingali and Xuan, 1992; Che et al., 2001; Ravallion and Van de Walle, 2008; Kompas et al., 2012). Part of the reform process and the transition to a market economy was the promulgation of 1988, 1993 and 2003 land laws and their subsequent revisions in 1998 and 2001, and the most recent land law in 2013. Land users are always required to use land as per its 'use purpose', and the state reserves the right to monitor, change or grant permission to any changes to land use. However, not until the 2001 revision (Article 1, point \#8) had rice land been explicitly specified in a land law. Before that, it was lumped together under agricultural land or annual crop agricultural land designations.

Quantitative indicators of rice land protection are articulated in Decree No. 63/NQ-CP, issued in 2009. In particular, 3.8 million hectares of rice land requires protection to yield an output of 41-43 million paddy rice/year so that food security in Vietnam is ensured by 2030. Furthermore, Resolution 17/2011/QH13 issued in 2011 details that 3.2 out of 3.8 million hectares of protected rice land must be land where (at least) two crops of rice are planted annually, implying a total of 7 million hectares of planted rice land. This ALP-byzoning measure is undertaken on the grounds that the government, the sole land owner in Vietnam by Constitution, has the ultimate power on land use which it classifies as of 'national importance' (article 54, Vietnam's Constitution). To facilitate this rice land protection, Decree 35/2015/ND-CP issued in 2015 provides measures to support (or not) rice farmers and procedures for conversion of rice land into other agricultural crops or production activities. In particular, rice land can be converted in a way that does not substantially change the heavily funded irrigation system, and rice can be planted again easily on the converted 
land (Article 4, Decree 35/2015/ND-CP). In addition, the government has been explicitly encouraging expansion of cultivated land for maize to reduce imports of livestock feed which Vietnam increasingly needs (Decision 899/QD-TTg promulgated in 2013 on restructuring Vietnam's agriculture). While using rice land for aquaculture is another option approved by the government, this kind of conversion is limited to delta regions, notably the Mekong, and would involve a substantial cost. Any other use of rice land for non-agricultural purposes is not allowed by the government given its concerns over food security.

Thus far Vietnam's administrative measures have been largely successful in land rice protection. Planted rice land in Vietnam has remained stable at roughly 7.5 million hectares since 2001 (General Statistic Office, 2016b, 2011). However, this rice land protection policy, together with various kinds of support and subsidies provided to rice farmers, results in an apparent inefficiency; notably, some rice land being left idle due to low incomes from rice production, coupled with a lack of crop choice, compared to higher returns and land shortages for other crops (VOV, 2013; Markussen et al., 2011; Tien et al., 2006). Consequently, rice farmers cannot maximize their profits due to the lack of freedom in crop choice, the rice sector is not very responsive to market signals and consumers are made worse off (Markussen et al., 2011; Giesecke et al., 2013). Thus, an adjustment towards more efficient land use can potentially improve Vietnam's prosperity, especially for rural households who account for two-thirds of Vietnam's population.

\section{Methodology}

We overlay a stochastic dynamic optimization model on top of a GE framework to answer the question how much rice land should be protected in Vietnam. A GE framework is needed to evaluate the economy-wide impact of land allocation while a dynamic optimization routine is required to investigate how much rice land would generate the highest real GDP in the medium-term. To mimic the situation where Vietnam is an open economy, thus being exposed to exogenous shocks in the world market, we propose a stochastic optimization 
dynamic problem in the form

$$
\max _{0 \leq r \leq 1} \sum_{t=1}^{T}\left\{\left(\frac{1}{1+\rho}\right)^{t-1} \mathbb{E}_{u}\left\{\left[\operatorname{GDP}_{t}(r)-\operatorname{GDP}_{t}(0)\right] \mid u\right\}\right\}
$$

where $\rho$ is a discount rate; $\mathbb{E}$ is an expectation operator, $u$ are random noises caused by exogenous factors; $T=10$ is the actual planning horizon in Vietnam; given the realisation of $u, \operatorname{GDP}_{t}(r)$ is the real GDP at year $t$ associated with a proportion $r$ of rice land converted into land for other crops while $\operatorname{GDP}_{t}(0)$ is the real GDP at year $t$ when no rice land is converted at all. Throughout the planning horizon, the conversion ratio remains constant to be consistent with the policy-making practice in Vietnam. Our objective is to find the value for the conversion ratio $r$ that maximizes the total real GDP over the planning horizon. Technically, $r$ can be negative in our model, that is, more rice land needs to be protected than currently. However, intuitively, rice area is apparently over-protected in Vietnam as discussed in Section 2. Under this circumstance, our discussion is limited to the cases of non-negative $r$ (while results for the cases of negative $r$ are available upon request).

With a GE framework nested inside, our stochastic dynamic optimization problem is computationally demanding. Furthermore, due to limited detailed information on the returns to alternative land uses, we have to keep our GE framework aggregate and basic. Since GDP focuses entirely on the overall economic efficiency of the economy, we complement this indicator by an index on inequality. In particular, we calculate the Gini index for each conversion ratio using GE framework outcomes of relative price changes and household income data. Finally, as both GDP and Gini indicators are aggregate, we provide insights on household welfare and distributional impacts of the optimal conversion ratio by region and socio-economic group with a micro-simulation.

The remainder of this section describes the structure of our GE framework, and the calibration and measurement of the Gini index, household welfare and distributional impacts. 


\subsection{GE framework: measuring real GDP}

Our dynamic GE framework models an open economy with a representative household. Domestic producers are divided into three industries, with government demands, investment and international trade. The three production industries include rice, non-rice and others of which rice represents all types of rice; non-rice consists of other staple food, vegetables and some annual industrial crops that can be planted on rice land and vice versus ${ }^{1}$; and others is made of all remaining commodities in the economy. Production uses five input factors, namely capital $(K)$, labour $(N)$ and three different land types for three produced goods ( $L^{\text {rice }}, L^{\text {non-rice }}$ and $L^{\text {others }}$ ). At each time $t \in[1, T]$, the GE framework outcome also depends on the conversion ratio $(r)$ and the realisation of uncertain factors $(u)$ specified in equation (1), which we suppress here for ease of reading.

The structure of our GE framework can generally be characterized by five main sets of conditions. The first one specifies the total supply being equal to the total demand in three industries:

$$
\begin{aligned}
& q_{t}^{i}=\sum_{s \in S} Q_{t}^{s, i} \\
& \text { for } \quad i \in\{\text { rice, non-rice, others }\}, s \in S=\{\text { rice, non-rice, others, } H, G, I, E x\}
\end{aligned}
$$

where at time $t, q_{t}^{i}$ is the supply of industry $i ; Q_{t}^{s, i}$ is the demand of sector $s$ for the output $i$; $E x, H, G$ and $I$ denote exports, household, government and investment sectors, respectively.

The second set of conditions are zero profit conditions in three industries:

$$
\begin{aligned}
& w_{t}^{i} q_{t}^{i}=R^{i} w_{t}^{i} q_{t}^{i}+K_{t}^{i} w_{t}^{K}+N_{t}^{i} w_{t}^{N}+L_{t}^{i} w_{t}^{L_{i}}+\sum_{j} Q_{t}^{i, j} w_{t}^{j}, \\
& \text { for } i \in\{\text { rice,non-rice, others }\}, j \in\{\text { rice, non-rice, others, Im }\}
\end{aligned}
$$

\footnotetext{
${ }^{1}$ Specifically, non-rice includes staple foods other than rice (e.g., maize, cassava, wheat, etc.), starchy and tuber crops (e.g. potatoes, sweet potatoes, taro, etc.), nuts (e.g. peanuts, sesame, etc.), vegetables (e.g. beans, cabbage, peas, etc.), flowers, fast growing fruit crops (e.g. water melon, papaya, banana, etc.) some industrial crops (sugar cane, tobacco, cotton etc.). Land for planting these crops can be used to plant rice and vice versus.
} 
where $w_{t}^{i}$ is the price of commodity $i ; w_{t}^{K}, w_{t}^{N}$ and $w_{t}^{L^{i}}$ are the prices of capital, labor and three types of land; $I m$ is imports so $w_{t}^{I m}$ is the price of import which is normalized to one; $R^{i}$ is the sale tax rate exogenously imposed on the production industry $i$; and $Q_{t}^{i, j}$ is the industry $i$ 's demand for input $j$.

The third set of conditions requires household expenditure to be equal to its income which includes after-tax income from production factors and government transfers:

$$
\begin{aligned}
& y_{t}^{H}=w_{t}^{K} K_{t}\left(1-R^{K}\right)+w_{t}^{N} N_{t}\left(1-R^{N}\right)+\sum_{i} w_{t}^{L^{i}} L_{t}^{i}\left(1-R^{L^{i}}\right)+y_{t}^{G H}, \\
& \text { for } \quad i \in\{\text { rice, non-rice, others }\}
\end{aligned}
$$

where $y_{t}^{H}$ is household expenditure, $R^{K}, R^{N}$, and $R^{L^{i}}$ are the tax rates exogenously imposed on capital, labor and three types of land, respectively, and $y_{t}^{G H}$ is the government transfer to households.

The fourth set of conditions implies that the total capital, labor, and land allocated to the three industries is equal to their corresponding resources available in the economy under the full employment assumption. Here we consider three constraint modelling cases. The first case is an equality-constrained condition which says that rice land protection is followed precisely as per the minimum threshold required by the government. The problem with this specification is that rice land can not be expanded even when doing so is more efficient, although an expansion is 'allowed' due to no restriction being imposed on converting nonrice land into rice land. This case is called "exact protection" and is typically specified in GE models for tractability ${ }^{2}$. We specify this scenario using the following equations:

\footnotetext{
${ }^{2}$ For example, Nielsen (2003) modelled a shift of $5 \%$ rice land into other agricultural uses in Vietnam.
} 


$$
\begin{cases}\mathbb{K}_{t} & =\sum_{i} K_{t}^{i}, \quad \text { for } \quad i \in\{\text { rice, non-rice, others }\} \\ \mathbb{N}_{t} & =\sum_{i} N_{t}^{i}, \quad \text { for } \quad i \in\{\text { rice, non-rice, others }\} \\ \mathbb{L}^{\text {others }} & =L_{t}^{\text {others }} \\ \mathbb{L}^{\text {non-rice }}+\mathbb{L}^{\text {rice }} r & =L_{t}^{\text {non-rice }} \\ \mathbb{L}^{\text {rice }}(1-r) & =L_{t}^{\text {rice }}\end{cases}
$$

where the first two equations in the system (5) refer to the full employment assumption for capital and labour; the third equation implies that all available others land is used in others industry; and the last two equations say that rice land planted is exactly equal to its specified protected area and non-rice land is expanded to absorb all newly released rice land if any. It is worth noting that the left-hand-side in the system (5) denotes the total available resources, and the time index $t$ is only needed in equations of capital and labour whose dynamics will be specified later in this subsection.

The second case also presents an equality-constrained condition but differs from the first case in having no restriction on crop choice between rice and non-rice. This case is typical for ALP in most countries that are concerned about food security, and want to protect land for a group of staple food which can be substituted for one another rather than protecting one particular staple. This case is called "free crop choice". The full employment assumption is formalized in a similar way as in the system (5) except the last two equations being in the form:

$$
\begin{cases}\mathbb{L}^{\text {rice }}+\mathbb{L}^{\text {non-rice }} & =L_{t}^{\text {rice }}+L_{t}^{\text {non-rice }} \\ \left(1-R^{L_{\text {rice }}}\right) w_{t}^{\text {rice }}-\left(1-R^{L_{n o n-r i c e}}\right) w_{t}^{\text {non-rice }} & =0\end{cases}
$$

where $R^{L_{\text {rice }}}$ and $R^{L_{\text {non-rice }}}$ are land taxes on rice and non-rice land. In essence, equations in (6) say that rice and non-rice land is constrained by the common pool of land in these two industries, and are allocated in a manner that equalizes their rental rates.

The third case resembles the policy context in Vietnam using an inequality-constrained condition. Here, the land protected quantity is the minimum rice land area, and farmers can expand their rice production using more land from non-rice crops until the rental rates in two industries are equalized. We call this case "minimum protection". We formalize this 
case by changing the last two equation in the system (5) using the Kuhn-Tucker conditions as follows:

$$
\begin{cases}\mathbb{L}^{\text {rice }}+\mathbb{L}^{\text {non-rice }} & =L_{t}^{\text {rice }}+L_{t}^{\text {non-rice }} \\ \mathbb{L}^{\text {Rice }}(1-r) & \leq L_{t}^{\text {Rice }} \\ {\left[L^{\text {rice }}-\mathbb{L}^{\text {rice }}(1-r)\right]\left[\left(1-R^{L_{\text {rice }}}\right) w_{t}^{\text {rice }}-\left(1-R^{L_{\text {non-rice }}}\right) w_{t}^{\text {non-rice }}\right]} & =0\end{cases}
$$

Mathematically, this case is the combination of the first and second cases.

The final set of conditions captures the dynamics of total capital and labor:

$$
\begin{array}{ll}
\mathbb{N}_{t+1}=(1+g) \mathbb{N}_{t} & \text { for } t=0,1, \ldots, T-1 \\
\mathbb{K}_{t+1}=\mathbb{K}_{t}+\theta I_{t}-\delta \mathbb{K}_{t} & \text { for } t=0,1, \ldots, T-1
\end{array}
$$

where $g$ is annual working labour growth rate; $I_{t}$ is real investment; $\theta$ is the transformation rate of investment into new capital; and $\delta$ is the depreciation rate of existing capital. Other conditions in our GE framework follow those in standard models (e.g. Dixon et al., 1992) and are detailed in Appendix A. Finally, GDP is calculated using the expenditure approach:

$$
\mathrm{GDP}_{t}=\sum_{i}\left[\left(Q_{t}^{H, i}+Q_{t}^{G, i}+Q_{t}^{I, i}+Q_{t}^{e x, i}\right) w_{0}^{i}\right]-w_{0}^{i m} \sum_{j} Q_{t}^{j, i m}
$$

for $i \in\{$ rice,non-rice, others $\}$ and $j \in\{$ rice,non-rice, others, $H, G, I\}$.

To conclude this sub-section, it is important to note that our GE framework is simple but relevant for the policy context discussed earlier. Notably, the interaction between rice and non-rice industries is of particular significance in our search for the optimal conversion ratio $r$ since rice and non-rice industries use similar land, but have to pay different rental rates due to government restrictions on crop choice for rice designated land. Such interactions are key in our GE framework, and thus land for each industry is modelled explicitly to accomodate the discrepancies in rental rates among industries. To this end, GDP changes with land reallocation across sectors which is plausible due to enhanced efficiency, thus enabling the 
optimization process. This feature makes our GE framework distinct from previous GE models on Vietnam's rice land policy despite the general consensus that a wedge in rental rates between designated rice land and other land uses exists (e.g. Rutten et al., 2014; Giesecke et al., 2013; Nielsen, 2003). Another feature that distinguishes our model from previous models is that we model an inequality-constrained case which best resembles the policy context in Vietnam in addition to the typical equality-constrained case in previous studies.

\subsection{GE framework: calibration}

The calibration of our GE framework broadly follows the standard method (Wing, 2004; Dawkins et al., 2001). In particular, we obtain estimates from existing studies for some parameters and use this information together with SAM to calibrate the remaining parameters, while solving for the values of endogenous variables. These parameters will be described in detail in the section on data and are subject to a sensitivity analysis, in the section on results, to check if the results of our stochastic dynamic optimization problem are robust.

Information on the transformation rate of investment into new capital (parameter $\theta$ in equation (9)) is highly important in our model given the model's dynamic nature and our focus on GDP. However, $\theta$ is country specific, and its estimates for Vietnam are hardly available. To address this problem, we use an empirical tuning approach and calibrate this parameter so that the GDP growth in our dynamic GE closely matches the actual growth path in Vietnam. This tuning is repeated in our sensitivity analysis of model-specified parameters.

Finally, it is worth mentioning that our model calibration differs from previous studies on Vietnam's rice land policy, despite also broadly following the standard calibration method. That is, we do not use the assumption that the economy is in equilibrium with an optimal allocation of resources as used previously (e.g. Nielsen, 2003). This assumption is apparently violated due to the government distortion in the land market, leading to discrepancies in rental rates among different land types (Markussen et al., 2011; Giesecke et al., 2013). Although Giesecke et al. (2013) mimic this situation using a phantom tax, here, we take a 
step further by separating land by industry, thus allowing the rental rates being different across land types. With this model design and SAM, we hope to largely capture the extent of rental differences and their impact on GDP.

\subsection{Micro-simulation: measuring changes in inequality and household welfare}

Using household survey data, we measure overall inequality using the income Gini index proposed by Gini (1921) as:

$$
\mathrm{Gini}_{t}=\frac{\sum_{h_{1}=1}^{n} \sum_{h_{2}=1}^{n} y_{t}^{h_{1}}-y_{t}^{h_{2}}}{2 n^{2} \sum_{h=1}^{n} y_{t}^{h}}
$$

where $n$ is the household sample size; at time $t$ for $t \in[1, T]$, Gini ${ }_{t}$ is the Gini index and $y_{t}^{h}$ is the income of a particular household $h$ which is different from $y_{t}^{H}$, the income of a representative household in the GE framework. Here $y_{t}^{h}$ is measured as:

$$
\begin{aligned}
& y_{t}^{h}=\sum_{i} q^{h, i} w_{t}^{h, i} \\
& \text { for } \quad i \in\{\text { rice, non-rice, others, capital,labour, rice-land,non-rice-land, others-land }\}
\end{aligned}
$$

where $q^{h, i}$ denotes the net supplied quantity of commodity/factor $i$ from household $h$; and $w_{t}^{h, i}$ is the price of commodity $i$ at time $t$ faced by household $h$. Note that $q^{h, i}$ differs from the supply $q_{t}^{i}$ of the whole industry $i$ while $w_{t}^{h, i}$ is not exactly the same with the price $w_{t}^{i}$ faced by the representative household in the GE framework due to regional and spatial variation in the sample. When the rice land conversion ratio $(r)$ changes and uncertain factors $(u)$ are realized, values of the endogenous variables in our GE framework, including prices and quantities supplied, change accordingly. We use the price outcome together with the data from a household survey to calculate the Gini index for each level of $r$ and the realisation of $u$. Thus the percentage change in income inequality for year $t, \Delta I E Q_{t}(r)$, caused by the change in rice land policy is measured as:

$$
\Delta I E Q_{t}(r)=\frac{\operatorname{Gini}_{t}(r)-\operatorname{Gini}_{t}(0)}{\operatorname{Gini}_{t}(0)}
$$


where $\operatorname{Gini}_{t}(r)$ is the income Gini index when a proportion $r$ of the current rice land is converted into non-rice land and $\operatorname{Gini}_{t}(0)$ is the income Gini index when no rice land is converted. Here we use the income Gini index instead of an expenditure index since this index is relatively more common and is also used as the official indicator on inequality in Vietnam.

In like manner, the change in welfare is also calculated using GE price outcomes and household data. Following Deaton (1989), this change is a combination of changes in consumer and producer surpluses induced by price variations when rice land policy adjusts since a household (especially in rice production) can be a consumer, or a producer, or both. This approach to measuring welfare change has been applied widely in welfare analysis of food policy in the world ${ }^{3}$. Accordingly, $\Delta C S_{t}^{h, i}(r)$ - the change in consumer surplus in consuming commodity $i$ of household $h$ at time $t$ associated with the conversion ratio $r-$ is defined as:

$$
\Delta C S_{t}^{h, i}(r) \cong-C^{h, i}\left[w_{t}^{h, i}(r)-w_{t}^{h, i}(0)\right]=-\underbrace{C^{h, i} w_{t}^{h, i}(0)}_{\text {Consumption value }} \underbrace{\frac{\Delta w_{t}^{h, i}}{w_{t}^{h, i}(0)}}_{\% \text { change in price }}
$$

for $i \in\{$ rice, non-rice, others, Im $\}$

where $C^{h, i}$ is the quantity demanded and $\Delta w_{t}^{h, i}$ is the change in the price. We assume that consumption does not change over time to avoid aggregation problems in economic modelling. Under this assumption, $\Delta C S_{t}^{h, i}(r)$ is a product of its initial consumption value and the percentage change in price which comes from the GE framework and is assumed to be uniform across households.

Since the first-order approximation reflects only the immediate or short-run impact of the price change, we also consider the second-order approximation which takes into account

\footnotetext{
${ }^{3}$ See for example, Budd (1993) for Cote d'Ivoire, Barrett and Dorosh (1996) for Madagascar; and Friedman and Levinsohn (2002) for Indonesia; Valero-Gil and Valero (2008) for Mexico, Minot and Goletti (1998); Vu and Glewwe (2011); Ha et al. (2015) for Vietnam, Ivanic and Martin (2008) for developing countries, among others.
} 
the consumer's response (or the long-term impact) in the form:

$$
\Delta C S_{t}^{h, i}(r) \cong-C^{h, i} w_{t}^{h, i}(0) \frac{\Delta w^{h, i}}{w_{t}^{h, i}(0)}-0.5 \varepsilon_{d}^{i} C^{h, i} w_{t}^{h, i}(0)\left[\frac{\Delta w^{h, i}}{w_{t}^{h, i}(0)}\right]^{2}
$$

where $\varepsilon_{d}^{i}$ is the own-price demand elasticity of commodity $i$.

Likewise, the second-order approximation of the change in producer surplus, $\Delta P S_{t}^{h, i}(r)$, can be calculated as follows:

$$
\Delta P S_{t}^{h, i}(r) \cong q^{h, i}\left[w_{t}^{i}(r)-w_{t}^{i}(0)\right] \cong \underbrace{q^{h, i} w_{t}^{h, i}(0)}_{\text {Revenues }} \underbrace{\frac{\Delta w_{t}^{h, i}}{w_{t}^{h, i}(0)}}_{\% \text { change in price }}+0.5 \varepsilon_{s}^{i} q^{h, i} w_{t}^{h, i}(0)\left[\frac{\Delta w^{h, i}}{w_{t}^{h, i}(0)}\right]^{2}
$$

for $i \in\{$ rice, non-rice, others, Im, capital, labour, rice-land, non-rice-land, others-land $\}$

where $\varepsilon_{s}^{i}$ is the own-price supply elasticity of commodity $i$.

Combining both changes in consumer and producer surplus, we use two indicators including the household net benefit, $N B_{t}^{h}(r)$, which is calculated as:

$$
N B_{t}^{h}(r)=\sum_{i}\left[\Delta P S_{t}^{h, i}(r)+\Delta C S_{t}^{h, i}(r)\right]
$$

for $i \in\{$ rice, non-rice, others, Im, capital, labour, rice-land, non-rice-land, others-land $\}$

and the average of household yearly net benefit ratio during the planning horizon, $\overline{N B R_{t}^{h}(r)}$, in the form:

$$
\overline{N B R_{t}^{h}(r)}=\frac{1}{T} \sum_{t} \frac{N B_{t}^{h}(r)}{Y^{h}}
$$

for $i \in\{$ rice, non-rice, others, Im, capital, labour, rice-land, non-rice-land, others-land $\}$

which compares the net benefit a household gains/looses each year against its initial wealth, proxied by its initial expenditure $Y^{h}$. 
Since households gain/loose over the whole planning horizon, following the usual practice in finance, we calculate changes in household consumer and producer surpluses and net benefit as annualized values ${ }^{4}$. Finally, for brevity, we only present results using the optimal conversion ratio $r^{\text {optimal }}$ obtained from our dynamic optimization in the minimum protection case.

\section{Model parameterization and data}

For the stochastic dynamic optimization model, information on the annual discount factor and distribution of stochastic noise is needed. For the former, we estimate $\rho$ as the real interest rate in Vietnam using the average of the difference between the government bond rate which represents the nominal interest rate, and the consumer price index, which approximates the inflation rate in Vietnam, during the period 2007-2015 (IMF, 2017). For the latter, we focus on the volatilities caused by Vietnam's rice yield and the world demand for Vietnamese rice since they are random (e.g., due to good/bad weather) and have a large impact on rice production and prices in Vietnam. An example of this shock is when Vietnam experiences good weather in a particular year, resulting in a higher rice yield, more rice output and exports to the world. Concurrently, other key rice exporters-countries in Asia would likely enjoy good weather as well. Under this circumstance, there would be much higher rice supply in the world, leading to less demand for Vietnamese rice. Therefore, Vietnam's rice exports and domestic prices would eventually fall in that year. Put differently, there are two primary sources of volatilities in place which are highly correlated. They are modelled as noise which have variances and covariance of Vietnam and world rice yield data during 2003-2013 (IRRI, 2016), added to the TFP trend in domestic rice production and the shift parameter in the export demand for Vietnam's rice.

Regarding the GE framework, we need a suitable SAM table and values for modelspecified parameters. The SAM table (Table 1) is compiled based on the 2011 SAM for

\footnotetext{
${ }^{4}$ In particular, we multiply each net present values of the streams of surpluses and net benefits with $(1-\kappa) /\left[\kappa\left(1-\kappa^{T}\right)\right]$ where $\kappa=\frac{1}{1+\rho}$.
} 
Vietnam constructed by CIEM-WIDER (2014), while model-specified parameters including CES coefficients for production and consumption functions, price elasticities of exports, annual depreciation of capital and growth of labour are presented in Table 2. The modelspecified parameters are largely estimated using recent data for Vietnam in a series of students' research master essays under direct supervision of one co-author (and available upon request), with the remaining drawn from the literature. The annual depreciation of capital (equation 9) is 10\% as per Decision 1940-QD-BTC issued by Vietnam's Ministry of Finance (MOF, 2015). Finally, annual labour force growth (equation 8) is 1\% to take into account both the past average growth of 1.7\% during 2010-2014 in Vietnam (General Statistic Office, 2016b) and the population growth forecasted for Vietnam to decrease from 1\% in 2017 to $0.6 \%$ in 2027 (FAO, 2017).

Microsimulation requires information on demand and supply elasticities (Appendix B) and household data. For the former, there are quite a few estimates for demand elasticities for rice and food commodities which vary across studies due to sample variation and different estimation methods (Vu, 2008; Le, 2008; Benjamin and Brandt, 2004; Minot and Goletti, 2000). We choose the Marshallian own-price elasticity estimates by Vu (2008) since the author uses the most updated data (VHLSS 2006) ${ }^{5}$, corrects for both quality and measurement error problems which are common in household data, and are available by quintile, urban/rural and by region. Furthermore, his estimates for rice and staples are suitable for rice and non-rice in our paper. Since estimates for others are not available for Vietnam, we use the average, weighted by the expenditure share, of the demand elasticity estimates by $\mathrm{Vu}(2008)$ for all other food groups rather than rice and staples. While this estimate may not be precise since others include both food other than rice and staples, and non-food, it would not substantially affect our results because the price changes for others are expected to be small given resources are being reallocated mainly between rice and non-rice sectors.

\footnotetext{
${ }^{5}$ Except for (Le, 2008), all other studies use data collected in 1990s which do not reflect the changing diet of Vietnamese as income has increased considerably even since.
} 
Table 1: 2011 Social accounting matrix for Vietnam (million USD in 2011 price)

\begin{tabular}{|c|c|c|c|c|c|c|c|c|c|c|c|c|c|}
\hline & rice & non-rice & others & Capital & Labor & $\begin{array}{l}\text { rice } \\
\text { land }\end{array}$ & $\begin{array}{c}\text { non-rice } \\
\text { land }\end{array}$ & $\begin{array}{l}\text { others } \\
\text { land }\end{array}$ & H'holds & Gov't & Inv'ment & Export & Total \\
\hline rice & 2200 & 25 & 3177 & & & & & & 4888 & & & 3119 & 13407 \\
\hline non-rice & 584 & 210 & 2140 & & & & & & 797 & & & 532 & 4261 \\
\hline others & 1875 & 669 & 141657 & & & & & & 72094 & 7428 & 27982 & 107485 & 359189 \\
\hline Capital & 556 & 183 & 50815 & & & & & & & & & & 51553 \\
\hline Labor & 4153 & 884 & 64903 & & & & & & & & & & 69940 \\
\hline rice land & 2551 & 0 & 0 & & & & & & & & & & 2551 \\
\hline non-rice land & 0 & 1799 & 0 & & & & & & & & & & 1799 \\
\hline others land & 0 & 0 & 5596 & & & & & & & & & & 5596 \\
\hline Households & & & & 38665 & 69940 & 2449 & 1709 & 5209 & & 15047 & & & 133018 \\
\hline Government & 161 & 36 & 18326 & 12888 & & 102 & 90 & 387 & 3794 & & & & 35784 \\
\hline Saving & & & & & & & & & 13375 & 12172 & & 2435 & 27982 \\
\hline Import & 1328 & 458 & 72576 & & & & & & 38071 & 1137 & & & 113570 \\
\hline Total & 13407 & 4261 & 359189 & 51553 & 69940 & 2551 & 1799 & 5596 & 133018 & 35784 & 27982 & 113570 & \\
\hline
\end{tabular}

Source: compiled based on CIEM-WIDER (2014) and (General Statistic Office, 2016b) 
Table 2: Model-specified parameters in the GE framework

\begin{tabular}{l|l|l|l|l}
\hline \hline Parameter description & Notation & $\begin{array}{l}\text { Baseline } \\
\text { value }\end{array}$ & Sources & $\begin{array}{l}\text { Ranges for } \\
\text { sensitivity } \\
\text { analysis }\end{array}$ \\
\hline $\begin{array}{l}\text { CES coefficient for rice pro- } \\
\text { duction }\end{array}$ & $\sigma^{\text {rice }}$ & 0.45 & Hoang (2015) & {$[0.35,0.55]$} \\
\hline $\begin{array}{l}\text { CES coefficient for } \text { non-rice } \\
\text { production }\end{array}$ & $\sigma^{\text {non-rice }}$ & 0.45 & Hoang (2015) & {$[0.35,0.55]$} \\
\hline $\begin{array}{l}\text { CES coefficient for others } \\
\text { production }\end{array}$ & $\sigma^{\text {others }}$ & 1 & Gabriel and Daniel $(2014)$ & {$[0.7,1.3]$} \\
\hline $\begin{array}{l}\text { Price elasticity coefficient } \\
\text { of rice exports }\end{array}$ & $\varepsilon^{\text {rice }}$ & -0.75 & Chowdhury (2015) & {$[-0.95,-0.55]$} \\
\hline $\begin{array}{l}\text { Price elasticity coefficient } \\
\text { of } n \text { non-rice exports }\end{array}$ & $\varepsilon^{\text {non-rice }}$ & -0.7 & Dang (2015) & {$[-0.9,-0.5]$} \\
\hline $\begin{array}{l}\text { Price elasticity coefficient } \\
\text { of } \text { others } \text { exports }\end{array}$ & $\varepsilon^{\text {others }}$ & -0.5 & Pham and Nguyen $(2013)$ & {$[-0.6,-0.4]$} \\
\hline $\begin{array}{l}\text { CES coefficient measuring } \\
\text { the substitutability in con- } \\
\text { sumption between necessity } \\
\text { and non-necessity goods }\end{array}$ & $\sigma^{H}$ & 0.05 & Hoang and Meyers $(2015)$ & {$[0.02,0.08]$} \\
\hline $\begin{array}{l}\text { Annual capital deprecia- } \\
\text { tion rate }\end{array}$ & $\delta$ & $10 \%$ & MOF (2015) & {$[5 \%, 15 \%]$} \\
\hline $\begin{array}{l}\text { Annual labor force growth } \\
\text { rate }\end{array}$ & $g$ & $1 \%$ & $\begin{array}{l}\text { General Statistic Office } \\
(2016 b) ; \text { FAO (2017) }\end{array}$ & {$[0.7 \%, 1.3 \%]$} \\
\hline Annual discount rate & $\rho$ & IMF (2017) & {$[2 \%, 4 \%]$} \\
\hline
\end{tabular}

Estimates of supply elasticities are available for rice and non-rice only (Khiem and Pingali, 1995). We assume that household supply elasticity for others is zero since households would not likely produce these goods. Meanwhile, labour supply elasticity is 0.46 (Domeij and Floden, 2006) while supply elasticities for other factors are assumed to be zero.

Household data come from VHLSS 2010, a nationally representative household survey. Although there are more updated versions of this data, we choose this survey since it was collected in a similar period to our SAM table. The data have 9,399 households interviewed on both income and expenditure. Finally, all values are reported in USD in 2011 prices using the exchange rate of $1 \mathrm{USD}=20,000$ VND unless otherwise specified. 


\section{Results}

Our aggregate results are obtained using Matlab, version 2014b, while our microsimulation is done using $R$, version 3.3.2. For each set of parameter values in the baseline, or in the range for checking the robustness of the aggregate result, empirical tuning is performed to find a suitable value of $\theta$ so that the GDP growth in our dynamic GE model closely matches the actual growth path in Vietnam. Once the value of a fitted $\theta$ is found, we simulate 1000 times for the whole 10-year planning horizon, so each year has 100 realisations of the stochastic term for each level of rice land conversion. The step in our search for the optimal land conversion ratio $r$ is single one-percentage point. To this end, solving the model and checking its robustness involves roughly 600,000 runs in total, not to mention the runs for empirical tuning to find $\theta$. Statistics in the microsimulation are also calculated using data from the runs for the optimal conversion ratio.

\subsection{Optimal rice land conversion ratio}

Figure 1 presents the total change in real GDP over 10 years associated with various rice land conversion ratios. All three constraint modelling cases suggest that the gain is about 2.3 billion $\$ \mathrm{US}$ when roughly $13 \%$ of rice land is converted into non-rice area. The gain in GDP is expected since resources are allocated in a more efficient way when the economy is moving from a suboptimal to an optimal allocation of land between rice and non-rice sectors, and land rental rates in these two sectors become equalized. The initial wedge in the rental rates or the inefficient allocation of land resources is evident in the SAM table with the rental rate of non-rice land being about USD 701/planted ha, twice as much as that of rice land being only USD 333/planted ha ${ }^{6}$.

Nonetheless, the relationship between the real GDP gain and rice land conversion ratio varies substantially across different constraint modelling cases despite their consensus at the maximum. For example, GDP gains remain the same beyond the optimal conversion ratio in

\footnotetext{
${ }^{6}$ That is, the total rental costs for rice and non-rice land are USD 2,551 million and USD 1,799 million as shown in Table 1, columns 2 and 3, respectively, for a total 7.655 million planted ha of rice land and 2.378 planted ha of non-rice land (General Statistic Office, 2016b).
} 
Figure 1: Land rice conversion and real GDP change

(a) Minimum Protection and Free Crop Choice

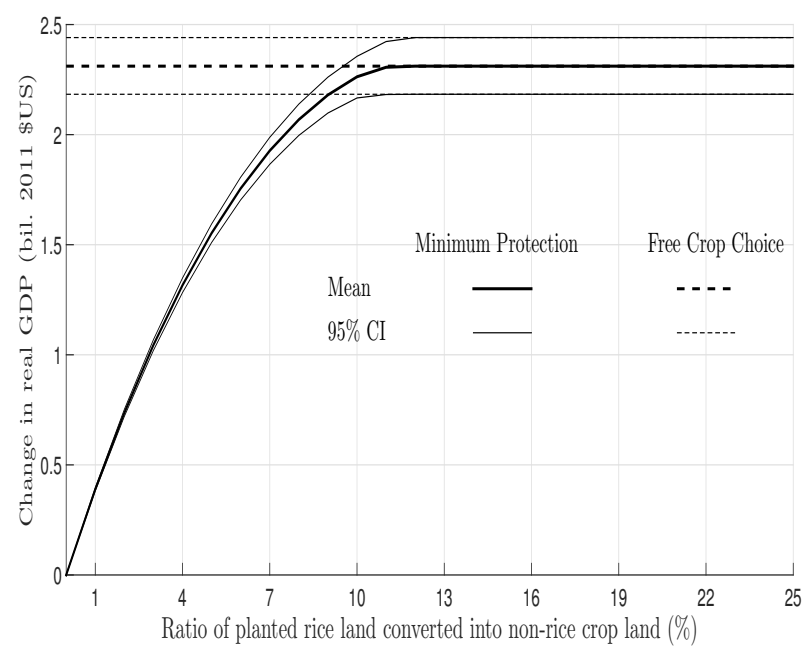

(b) Exact Protection

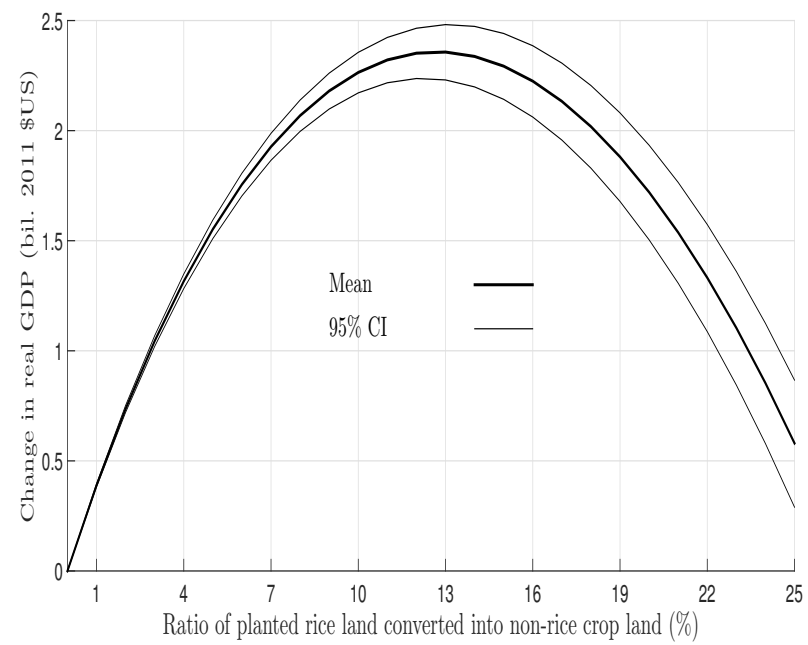

Minimum Protection but stays constant at the maximum throughout the whole range of the rice land conversion ratio in Free Crop Choice (Figure 1, panel (a)). Meanwhile, in Exact Protection case, the GDP gain is hump-shaped; that is, further increasing the conversion ratio beyond the optimal point results in a monotonic fall in GDP (Figure 1, panel (b)).

This difference across modelling cases is surprising at first, but turns out to be sensible for two reasons. First, real GDP is improved in Free Crop Choice due to no constraints imposed to prevent resources from being allocated optimally, so the economy moves right to the optimal allocation of resources. Since farmers can always choose to plant rice or non-rice crop in this case, GDP gains are not affected by rice the land conversion ratio. Second, the monotonic fall of GDP beyond the optimal point in Exact Protection is caused by the fact that farmers are modelled to follow exactly the land conversion ratio set by the government instead of treating it as a minimum as actually required. For example, suppose the government allows $15 \%$, at most, of the rice land to be converted into non-rice land while market general equilibrium prices suggest that only $13 \%$ of the rice land is needed for non-rice sector. In this circumstance, as farmers can convert $15 \%$ or less rice land into nonrice, they will choose the optimal ratio of $13 \%$ instead $15 \%$ to maximize their profit. This behaviour is modelled in Minimum Protection, leading to the stark difference in its outcome 
compared with that in Exact Protection in situations when government's land conversion threshold is higher than the optimal rice land conversion ratio. Put differently, Minimum Protection takes into account the optimal behaviour of farmers when the land use constraint imposed by the government is no longer binding while Exact Protection does not. The difference in outcomes by the three constraint modelling cases highlights the importance of modelling as closely as possible the policy context to avoid misleading results.

\subsection{Impact on inequality}

Figure 2 presents changes in overall equality in the three different constraint modelling cases. In Free Crop Choice, equality improved, though marginally, by $0.15 \%$ regardless of rice land conversion ratio. This result makes sense since the Gini index is income-based, and farmers, especially rice farmers, would be better off with free crop choice, narrowing the rural-urban income gap. Meanwhile, in Minimum Protection, the Gini index reduces gradually as the rice land conversion ratio approaches to the optimal level and then levels off (at the same level as in Free Crop Choice), when farmers can no longer increase their income. In contrast, inequality monotonically decreases as more rice land is converted into non-rice land in Exact Protection. This result is counter-intuitive, and, again, solely driven by the assumption that farmers follow precisely government policy on rice land allocation instead of behaving optimally. Indeed, beyond the optimal point, too little land is allocated to rice production, pushing up rice price against non-rice price. Incomes of rural households, most of whom have rice production as their primary source of income, will increase while that of urban households and non-farm (richer) rural households remains relatively unchanged, resulting in a monotonic decrease in inequality.

To sum up, if farmers have more crop choice, overall equality would likely improve, though slightly; albeit attention needs to be paid to the way constraints are modelled since results can be very much in error when constraints are non-binding.

\subsection{Impact on household welfare}

Unlike the Gini coefficient, NB and $\overline{N B R}$ look at the gain/loss in both consumption and income of a household. Results of the optimal rice land conversion policy are presented 
Figure 2: Land rice conversion and change in Gini index

(a) Minimum Protection and Free Crop Choice

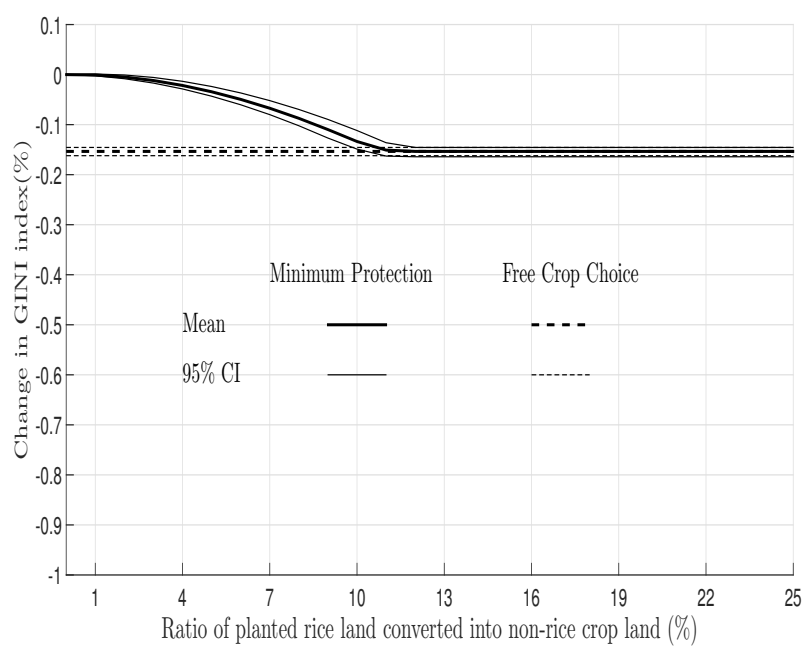

(b) Exact Protection

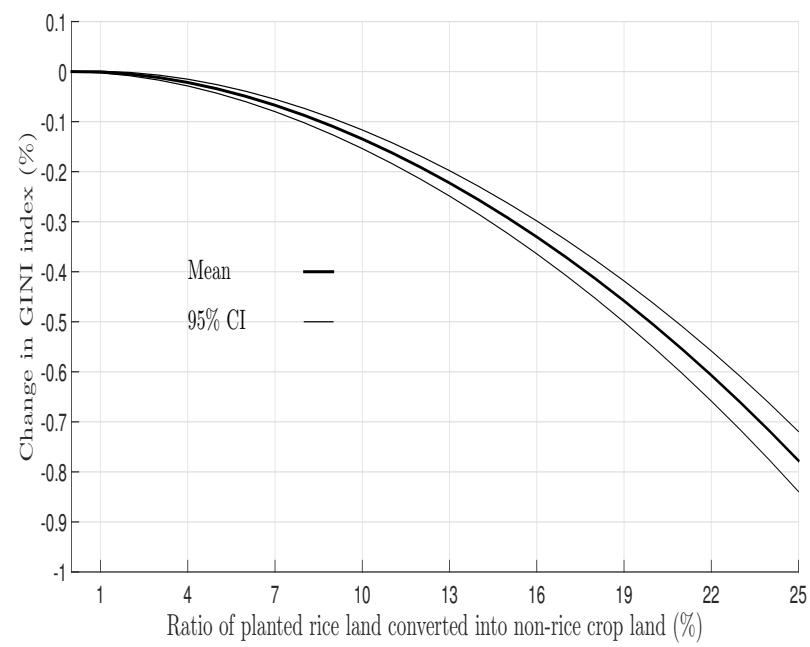

in Table 3. Since at an optimum point, outcomes are quite similar across three modelling cases, we focus on Minimum Protection. Households are classified based on their geographical region, urban-rural and wealth ranking status (columns 1-2). We define households as a net seller/net buyer/self-sufficient if their rice consumption value is smaller/larger than, or equal to their rice production value (columns 3-5). It can be seen that rice production is a rural activity with most rice net sellers being rural households, and rich households are less likely involved in rice production. Across regions, households in Central Highlands (CH) and South East (SE) are more likely to buy rice since the former has soil and climate conditions more suitable for crops such as coffee, cashew nuts, maize, etc., while the latter is the largest economic and manufacturing hub in Vietnam. Meanwhile, the Mekong River Delta (MRD) has as much as $70 \%$ of households being net buyers despite producing over $50 \%$ of rice in Vietnam, all caused by large-scale production in this region compared to others.

The short-run or immediate impact of the price change are presented in columns 6-9 while the long-run impact is in columns 10-13. There is little sensitivity between the two sets of results, and therefore, we only discuss the long-run impact. Most statistics are statistically significant at $1 \%$ level except for some changes in producer surplus for an average urban, rural and national households. 
Table 3: Household net position in rice, changes in annualized consumer surplus and producer surplus, net benefit (USD/per person) and average net benefit ratio (\%) over the planning horizon

\begin{tabular}{|c|c|c|c|c|c|c|c|c|c|c|c|c|}
\hline \multirow[b]{2}{*}{ Group } & \multicolumn{4}{|c|}{$\%$ of household } & \multicolumn{4}{|c|}{ Short-run impact } & \multicolumn{4}{|c|}{ Long-run impact } \\
\hline & $\begin{array}{l}\% \text { of } \\
\text { all hh }\end{array}$ & $\begin{array}{l}\text { Net } \\
\text { Seller }\end{array}$ & $\begin{array}{c}\text { Self } \\
\text { suffi- } \\
\text { cient }\end{array}$ & $\begin{array}{l}\text { Net } \\
\text { Buyer }\end{array}$ & $\begin{array}{c}\Delta \\
\mathrm{CS}\end{array}$ & $\begin{array}{c}\Delta \\
\text { PS }\end{array}$ & NB & $\begin{array}{l}\text { Benefit } \\
\text { Ratio }\end{array}$ & $\begin{array}{c}\Delta \\
\mathrm{CS}\end{array}$ & $\begin{array}{c}\Delta \\
\text { PS }\end{array}$ & $\mathrm{NB}$ & $\begin{array}{l}\text { Benefit } \\
\text { Ratio }\end{array}$ \\
\hline (1) & (2) & (3) & $(4)$ & (5) & (6) & (7) & (8) & (9) & (10) & (11) & (12) & (13) \\
\hline \multirow[t]{2}{*}{ All } & 100 & 33.8 & 0.4 & 65.8 & $2.0^{a}$ & 0.2 & $2.2^{a}$ & $0.01^{a}$ & $2.3^{a}$ & 0.2 & $2.5^{a}$ & $0.1^{a}$ \\
\hline & & & & & {$[0.000]$} & {$[0.2]$} & {$[0.000]$} & {$[0.000]$} & {$[0.000]$} & {$[0.2]$} & {$[0.000]$} & {$[0.000]$} \\
\hline \multirow[t]{2}{*}{ Urban } & 30.5 & 8.1 & 1.0 & 90.9 & $3.6^{a}$ & -0.2 & $3.4^{a}$ & $0.2^{a}$ & $3.9^{a}$ & -0.2 & $3.7^{a}$ & $0.3^{a}$ \\
\hline & & & & & {$[0.1]$} & {$[0.3]$} & {$[0.3]$} & {$[0.000]$} & {$[0.1]$} & {$[0.3]$} & {$[0.3]$} & {$[0.000]$} \\
\hline \multirow[t]{2}{*}{ Rural } & 69.5 & 45.0 & 0.2 & 54.8 & $1.2^{a}$ & $0.4^{b}$ & $1.6^{a}$ & $-0.1^{a}$ & $1.6^{a}$ & $0.4^{b}$ & $2.0^{a}$ & $-0.03^{a}$ \\
\hline & & & & & {$[0.05]$} & {$[0.2]$} & {$[0.2]$} & {$[0.000]$} & {$[0.1]$} & {$[0.2]$} & {$[0.2]$} & {$[0.000]$} \\
\hline \multirow[t]{2}{*}{ RRD } & 24.8 & 47.0 & 0.0 & 53.0 & $2.1^{a}$ & $1.9^{a}$ & $4.0^{a}$ & $0.5^{a}$ & $2.4^{a}$ & $2.0^{a}$ & $4.4^{a}$ & $0.6^{a}$ \\
\hline & & & & & {$[0.000]$} & {$[0.03]$} & {$[0.000]$} & {$[0.000]$} & {$[0.000]$} & {$[0.03]$} & {$[0.000]$} & {$[0.000]$} \\
\hline \multirow[t]{2}{*}{ MNM } & 12.6 & 47.5 & 0.2 & 52.3 & $-0.1^{a}$ & $-5.2^{a}$ & $-5.4^{a}$ & $-1.7^{a}$ & $0.2^{a}$ & $-5.2^{a}$ & $-5.0^{a}$ & $-1.6^{a}$ \\
\hline & & & & & {$[0.000]$} & {$[0.04]$} & {$[0.000]$} & {$[0.000]$} & {$[0.000]$} & {$[0.04]$} & {$[0.000]$} & {$[0.000]$} \\
\hline \multirow[t]{2}{*}{ NCC } & 21.7 & 40.5 & 0.0 & 59.5 & $1.5^{a}$ & $-2.6^{a}$ & $-1.2^{a}$ & $-0.4^{a}$ & $1.8^{a}$ & $-2.6^{a}$ & $-0.8^{a}$ & $-0.4^{a}$ \\
\hline & & & & & {$[0.000]$} & {$[0.1]$} & {$[0.000]$} & {$[0.000]$} & {$[0.000]$} & {$[0.1]$} & {$[0.000]$} & {$[0.000]$} \\
\hline \multirow[t]{2}{*}{$\mathrm{CH}$} & 5.4 & 19.5 & 0.3 & 80.2 & $1.0^{a}$ & $-9.1^{a}$ & $-8.1^{a}$ & $-2.3^{a}$ & $1.3^{a}$ & $-9.1^{a}$ & $-7.8^{a}$ & $-2.2^{a}$ \\
\hline & & & & & {$[0.000]$} & {$[0.05]$} & [0.001] & {$[0.001]$} & {$[0.000]$} & {$[0.05]$} & {$[0.001]$} & {$[0.001]$} \\
\hline \multirow[t]{2}{*}{$\mathrm{SE}$} & 16.8 & 3.9 & 1.9 & 94.2 & $3.7^{a}$ & $-2.8^{a}$ & $0.9^{a}$ & $-0.01^{a}$ & $4.0^{a}$ & $-2.8^{a}$ & $1.2^{a}$ & $0.02^{a}$ \\
\hline & & & & & {$[0.000]$} & {$[0.1]$} & {$[0.000]$} & {$[0.000]$} & {$[0.000]$} & {$[0.1]$} & {$[0.000]$} & {$[0.000]$} \\
\hline \multirow[t]{2}{*}{ MRD } & 18.8 & 30.1 & 0.3 & 69.6 & $2.5^{a}$ & $10.2^{a}$ & $12.7^{a}$ & $1.6^{a}$ & $2.9^{a}$ & $10.2^{a}$ & $13.2^{a}$ & $1.7^{a}$ \\
\hline & & & & & {$[0.000]$} & {$[0.1]$} & {$[0.000]$} & {$[0.001]$} & {$[0.000]$} & {$[0.1]$} & {$[0.000]$} & {$[0.001]$} \\
\hline \multirow[t]{2}{*}{ Poorest } & 8.0 & 45.8 & 0.2 & 54.0 & $-0.8^{a}$ & $-3.2^{a}$ & $-4.0^{a}$ & $-2.0^{a}$ & $-0.6^{a}$ & $-3.2^{a}$ & $-3.7^{a}$ & $-1.9^{a}$ \\
\hline & & & & & {$[0.000]$} & {$[0.02]$} & {$[0.000]$} & {$[0.001]$} & {$[0.000]$} & {$[0.02]$} & {$[0.000]$} & {$[0.001]$} \\
\hline \multirow[t]{2}{*}{ 2nd } & 9.2 & 42.8 & 0.2 & 57.0 & $-0.4^{a}$ & $-2.4^{a}$ & $-2.7^{a}$ & $-0.8^{a}$ & $-0.1^{a}$ & $-2.3^{a}$ & $-2.4^{a}$ & $-0.7^{a}$ \\
\hline & & & & & {$[0.000]$} & {$[0.02]$} & {$[0.000]$} & {$[0.000]$} & {$[0.000]$} & {$[0.02]$} & {$[0.000]$} & {$[0.000]$} \\
\hline \multirow[t]{2}{*}{ 3rd } & 9.1 & 48.7 & 0.1 & 51.2 & $0.1^{a}$ & $-1.7^{a}$ & $-1.6^{a}$ & $-0.4^{a}$ & $0.4^{a}$ & $-1.6^{a}$ & $-1.3^{a}$ & $-0.3^{a}$ \\
\hline & & & & & {$[0.000]$} & {$[0.04]$} & {$[0.000]$} & {$[0.001]$} & {$[0.000]$} & {$[0.04]$} & {$[0.000]$} & {$[0.001]$} \\
\hline \multirow[t]{2}{*}{ 4th } & 9.7 & 48.5 & 0.0 & 51.5 & $0.6^{a}$ & $0.8^{a}$ & $1.3^{a}$ & $0.3^{a}$ & $0.9^{a}$ & $0.8^{a}$ & $1.6^{a}$ & $0.3^{a}$ \\
\hline & & & & & {$[0.000]$} & {$[0.04]$} & {$[0.000]$} & {$[0.000]$} & {$[0.000]$} & {$[0.04]$} & {$[0.000]$} & {$[0.000]$} \\
\hline \multirow[t]{2}{*}{5 th } & 9.8 & 43.4 & 0.1 & 56.5 & $1.0^{a}$ & $0.7^{a}$ & $1.7^{a}$ & $0.3^{a}$ & $1.3^{a}$ & $0.7^{a}$ & $2.0^{a}$ & $0.3^{a}$ \\
\hline & & & & & {$[0.000]$} & [0.05] & {$[0.000]$} & {$[0.000]$} & {$[0.000]$} & {$[0.05]$} & {$[0.000]$} & {$[0.000]$} \\
\hline \multirow[t]{2}{*}{ 6th } & 10.0 & 40.3 & 0.6 & 59.1 & $1.5^{a}$ & $1.4^{a}$ & $2.9^{a}$ & $0.4^{a}$ & $1.8^{a}$ & $1.4^{a}$ & $3.2^{a}$ & $0.5^{a}$ \\
\hline & & & & & {$[0.000]$} & {$[0.05]$} & {$[0.000]$} & {$[0.000]$} & {$[0.000]$} & {$[0.05]$} & {$[0.000]$} & {$[0.000]$} \\
\hline \multirow[t]{2}{*}{ 7th } & 10.7 & 31.1 & 0.3 & 68.6 & $1.9^{a}$ & $0.6^{a}$ & $2.5^{a}$ & $0.3^{a}$ & $2.3^{a}$ & $0.6^{a}$ & $2.8^{a}$ & $0.4^{a}$ \\
\hline & & & & & {$[0.000]$} & {$[0.1]$} & {$[0.000]$} & {$[0.000]$} & {$[0.000]$} & {$[0.1]$} & {$[0.000]$} & {$[0.000]$} \\
\hline \multirow[t]{2}{*}{ 8th } & 10.8 & 27.9 & 0.2 & 71.9 & $2.7^{a}$ & $3.1^{a}$ & $5.9^{a}$ & $0.6^{a}$ & $3.1^{a}$ & $3.2^{a}$ & $6.2^{a}$ & $0.6^{a}$ \\
\hline & & & & & {$[0.000]$} & {$[0.1]$} & {$[0.000]$} & {$[0.000]$} & {$[0.000]$} & {$[0.1]$} & [0.000] & {$[0.000]$} \\
\hline \multirow[t]{2}{*}{ 9th } & 11.0 & 16.1 & 0.4 & 83.5 & $3.9^{a}$ & $2.4^{a}$ & $6.2^{a}$ & $0.5^{a}$ & $4.3^{a}$ & $2.4^{a}$ & $6.6^{a}$ & $0.5^{a}$ \\
\hline & & & & & {$[0.000]$} & {$[0.1]$} & {$[0.000]$} & {$[0.000]$} & {$[0.000]$} & {$[0.1]$} & {$[0.000]$} & {$[0.000]$} \\
\hline Richest & 11.7 & 5.3 & 1.7 & 93.0 & $7.0^{a}$ & $-0.9^{a}$ & $6.1^{a}$ & $0.3^{a}$ & $7.5^{a}$ & $-0.9^{a}$ & $6.5^{a}$ & $0.3^{a}$ \\
\hline & & & & & {$[0.000]$} & {$[0.1]$} & {$[0.000]$} & {$[0.000]$} & {$[0.000]$} & {$[0.1]$} & {$[0.000]$} & {$[0.000]$} \\
\hline
\end{tabular}

Notes: $\Delta=$ Change; $C S=$ Consumer Surplus; PS $=$ Producer Surplus; NB=Net Benefit; CS, PS and NB are annualized values; $\mathrm{RRD}=$ Red River Delta, $\mathrm{MNM}=$ Midlands and Northern Mountains, $\mathrm{NCC}=$ Northern and Coastal Central, $\mathrm{CH}=$ Central Highlands, $\mathrm{SE}=$ South East, $\mathrm{MRD}=$ Mekong River Delta. Standard errors are in square brackets. All statistics are calculated taking into account the VHLSS 2010 sampling design. (a) $p<0.01$, (b) $p<0.05$, (c) $p<0.10$. 
Overall, the optimal rice land conversion policy results in an increase of 2.5 USD in NB per person (column 12). Taking Vietnam's population of about 90 million people as a whole, the country NB is expected to increase by about 225 million USD. Urban dwellers gain 3.7 USD in NB per person, about double that of their rural counterparts. The positive impact on NB is largely driven by the gain in consumer surplus. This finding suggests that shifting away from rice to consuming more products in non-rice such as vegetables, fast-growing fruits, nuts, sugar, starchy and tuber crops, etc., imply that urban and rich consumers are likely better off when rice price increases and prices of non-rice fall. Furthermore, the modest gain from producer surplus of rural households indicates that rice production no longer plays a principal role in rural household activities, as it once did.

Turning to the average net benefit ratio $\overline{N B R}$, the impact is negligible at the country level, being $0.1 \%$ (column 13). Nonetheless, urban households gain while rural ones loose, though the magnitude is tiny. Note that all $\overline{N B R}$ and NB estimates are of the same sign in our results except for rural households. This difference in sign is possible, and in this case, it is due to significant variation in the sample, which we will discuss shortly, and the fact that $\overline{N B R}$ and NB measure closely related but different things.

Among six regions, MRD and, to a lesser extent, the Red River Delta (RRD) stand out as 'winners'. Only in these two regions do both consumers and producers benefit. In others, in contrast, consumers gain, but producers lose (columns 10-13). This result is similar to the one by Minot and Goletti (1998, table 1) who find that the impact of the trade liberalization also increases rice prices, with benefit to MRD and RRD. This similarity, together with the fact that we are using a more updated household dataset, corroborates a persistent pattern in the regional distribution of rice production and consumption in Vietnam. In particular, $\mathrm{CH}$ and Midlands and Northern Mountains (MNM) are the worst off, especially with regard to producer surplus (column 11), due to having soil largely suitable for non-rice. A $13 \%$ conversion of rice land into non-rice implies an increase of about $40 \%$ of total planted area for non-rice, which results in an increase in the supply of this sector. As a result, there is a massive fall in prices of non-rice, causing losses to its producers. Meanwhile, these two 
regions have the highest proportions of poor households, whose diet is dominated by rice, so consumer gains here are the lowest (column 10). On the contrary, SE, followed by MRD and RRD, enjoy the highest gain in consumer surplus due to their being the richest regions in the country.

Further disaggregated results by wealth decile reveal a pro-rich pattern of this rice land conversion policy. In column 10, a clear trend can be seen that richer households gain more consumer surplus than poorer ones. This trend points out an inevitable shift away from the heavy consumption of rice as the nation becomes richer, as found in other countries (Shoichi Ito, 1989). Regarding producer surplus, there exists no clear pattern, but it is evident that the poorest $30 \%$ households experience the largest losses. Coupled with their modest gain in consumer surplus, these groups are the biggest losers should this policy be implemented. The reason is clear. Likely living in difficult terrains, their primary source of income comes from maize, cassava, etc., while rice remains crucial in their diet. The reallocation of rice land which results in higher rice prices and lower non-rice prices, harms these households on both fronts.

\subsection{Sensitivity analysis}

We check whether our optimization model outcome is sensitive to its parameter values. Table 2 specifies the range of values for sensitivity analysis which is drawn either from the upper and lower bounds of the parameter estimates in the literature, or we vary them by $\pm 30 \%$ to $\pm 50 \%$. The model outcomes are presented in Figure 3 obtained when we change each parameter value at a time while keeping others at their baseline values. It can be seen that the optimal conversion ratio is hardly sensitive to most of the parameter values except the CES coefficients of rice and non-rice and, to a less extent, the price elasticity coefficient of others exports. This result is plausible for two reasons. First, since the policy shock to the 'business-as-usual' scenario is the reallocation of land betweenrice and non-rice sectors, their production function parameters are expected to be key to the model outcome. Second, although rice and non-rice are essential for household living standards, especially in rural areas, their combined export value is than $10 \%$ of total exports revenues in Vietnam (General 
Statistic Office, 2016a). Therefore, the capacity to export others might have some influence on land allocation in the other two sectors in the GE framework.

Figure 3: Sensitivity analysis of the optimal conversion rate

$$
\begin{aligned}
& \epsilon^{\text {others }} \in[-0.6,-0.4] \\
& \epsilon^{\text {non-rice }} \in[-0.9,-0.5] \\
& \epsilon^{\text {rice }} \in[-0.95,-0.55] \\
& \sigma^{H} \in[0.02,0.08] \\
& \sigma^{\text {others }} \in[0.7,1.3] \\
& \sigma^{\text {non-rice }} \in[0.35,0.55] \\
& \sigma^{\text {rice }} \in[0.35,0.55] \\
& \delta \in[5 \%, 15 \%] \\
& g \in[0.7 \%, 1.3 \%] \\
& \rho \in[2 \%, 4 \%]
\end{aligned}
$$

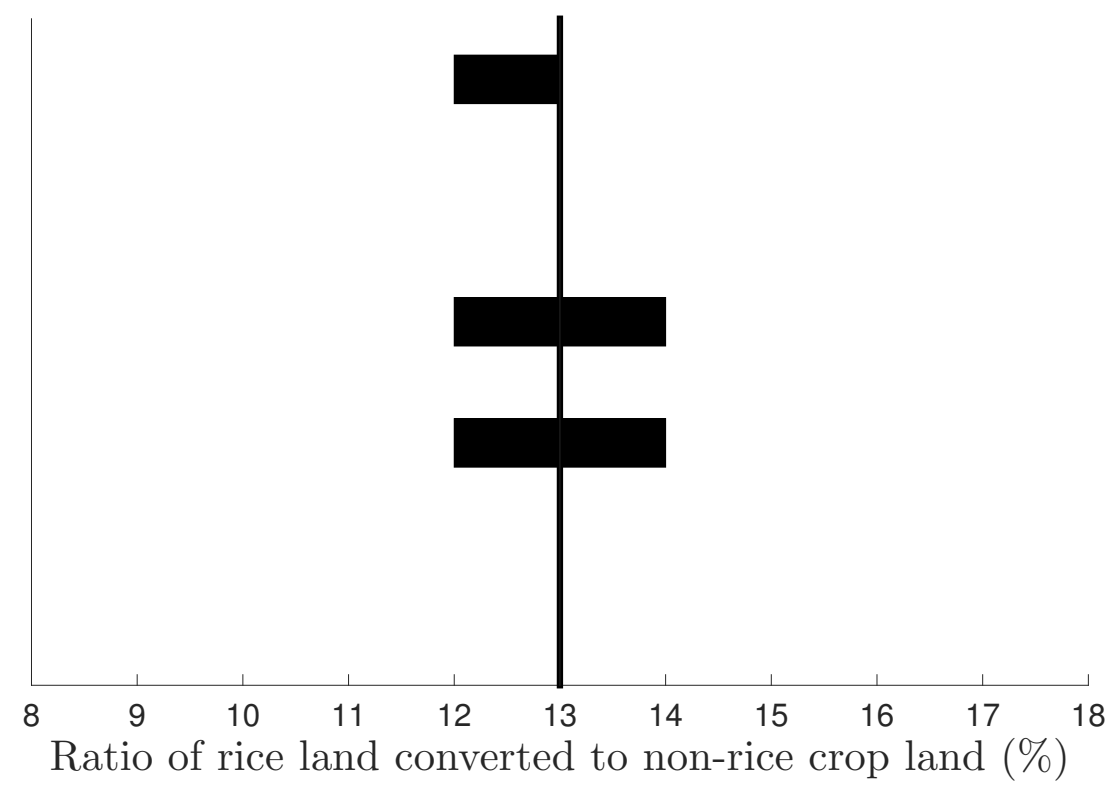

\section{Discussion}

This paper contributes to the literature on ALP by presenting the first attempt, to the best of our knowledge, to quantify how much land should be preserved for a particular crop. ALP has long been implemented for food security concerns in many countries but hardly justified using an optimization framework. This lack of policy guidance likely results in a sub-optimal outcome for the economy, as commonly found in exisiting literature.

Using the case of Vietnam where rice is a political and highly protected commodity, we investigate how much rice land should be released for use for other agricultural crops. While land policies tend to have multiple goals, we only focus on its economic efficiency measured by changes in GDP. Given Vietnam's declaration to develop a socialist-oriented market economy, we also investigate the implications of the optimal policy outcome on inequality and wealth distribution by region, urban, rural and wealth-rank status. 


\subsection{Policy implications}

Relatively robust to parameter values, we find that about one million hectares of planted rice land, or $13 \%$ of the existing planted rice land, should be released to other crops for an optimal efficiency gain. This gain is about 2.3 billion dollars in real GDP over the planning horizon of 10 years, with a slight overall reduction in income-based inequality by $0.15 \%$. Nonetheless, considering the policy impact on both income and consumption, the pattern is pro-rich. Indeed, as much as $30 \%$ of the poorest households, who likely live in the much less developed mountainous and highland regions of MNM and $\mathrm{CH}$, are negatively affected by this optimal policy. Since poverty tends to be chronic and persistent in these two regions, due to having difficult terrains and poor infrastructure, and Vietnam generally lacks effective social safety networks due to its low level of development, this outcome presents a challenge for decision-makers in Vietnam.

\subsection{Contributions, limitations and future works}

Existing economic literature on ALP largely focuses on the its welfare and efficiency impact or the amount of farmland lost. While providing useful insights, they provide little guidance to answer the question "how much land should be protected?" for policy-makers. We contribute to this knowledge gap by proposing the use of an optimization model built on top of a GE framework to find the best land allocation/protection that maximizes the economy's GDP. This aggregate analysis is supplemented by microsimulations to shed light on changes in inequality and distributional welfare impacts. To this end, our framework provides useful evidence to guide policy-making, rather than the practice of simply setting agricultural land aside in an arbitrary fashion.

Although being applied to rice land protection against other crops in Vietnam, our model is applicable to many land planning contexts. For example, it can be used to protect the production of a group of agricultural commodities versus other products, or to balance between pressures on agricultural land conversion driven by population increases and urbanization versus concerns over food security, environmental issues and uncertainty. In these situations, finding the optimal protection level or the right balance often requires a tool that can help 
evaluate economy-wide macro and micro impacts of different policy parameter values with a well-defined objective function. Indeed, one may expand our objective function beyond real GDP to include other economic, social and possibly environmental indicators of interest, weighted by policy-makers to reflect their priority.

Admittedly, our model remains quite basic because of the computational challenge in optimizing over a GE framework and the practical constraints in data. A significant improvement in this work (if and when better data and computational capacity is available) would be to account for a multi-dimensional policy space. For example, policy-makers may be interested in protecting agricultural land by combining involuntary zoning and complementary tax incentives for owners. In this case, policy parameters include both the quantities of zoning and the extent of tax incentives. Furthermore, the model can be extended to take into account spatial heterogeneity to determine optimal land protection at a more disaggregated level, to balance, for example, agricultural land preservation not only at a national level but also in each sub-region. 


\section{References}

Alterman, R. (1997). The challenge of farmland preservation: lessons from a six-nation comparison. Journal of the American Planning Association 63(2), 220-243.

Azadi, H., P. Ho, and L. Hasfiati (2011). Agricultural land conversion drivers: A comparison between less developed, developing and developed countries. Land Degradation 8 Development 22(6), 596-604.

Barrett, C. and P. Dorosh (1996). Farmers' welfare and changing food prices: nonparametric evidence from rice in madagascar. American Journal of Agricultural Economics 78(3), 656-669.

Bengston, D. N., J. O. Fletcher, and K. C. Nelson (2004). Public policies for managing urban growth and protecting open space: policy instruments and lessons learned in the United States. Landscape and urban planning 69(2), 271-286.

Benjamin, D. and L. Brandt (2004). Agriculture and income distribution in rural vietnam under economic reforms: a tale of two regions. In P. Glewwe, N. Agrawal, and D. Dollar (Eds.), Economic Growth, Poverty, and Household Welfare in Vietnam. World Bank: Washington D.C.

Brandt, L., J. Huang, G. Li, and S. Rozelle (2002). Land rights in rural China: facts, fictions and issues. The China Journal 47, 67-97.

Budd, J. (1993). Changing food prices and rural welfare: A nonparametric examination of the cote d'ivoire. Economic Development and Cultural Change 41(3), 587-603.

Che, T. N., T. Kompas, and N. Vousden (2001). Incentives and static and dynamic gains from market reform: rice production in vietnam. Australian Journal of Agricultural and Resource Economics 45(4), 547-572.

Chowdhury, R. (2015). An estimate of price elasticity of demand for vietnams rice exports. Master research essay, The Australian National University: Canberra.

CIEM-WIDER (2014). A 2011 social accounting matrix (SAM) for Vietnam. Labour and Social Publishing House: Hanoi.

Dang, V. (2015). An estimate of price elasticity of demand for vietnams corn exports. Master research essay, The Australian National University: Canberra.

David, C. C. and J. Huang (1996). Political economy of rice price protection in asia. Economic Development and Cultural Change 44(3), 463-483.

Dawkins, C., T. N. Srinivasan, and J. Whalley (2001). Calibration. In J. Heckman and E. Leamer (Eds.), Handbook of Econometrics. Elsevier.

Deaton, A. (1989). Rice prices and income distribution in Thailand: a non-parametric analysis. The Economic Journal $99(395), 1-37$. 
Deininger, K. W. et al. (2003). Land policies for growth and poverty reduction. World Bank Publications.

Deng, X., J. Huang, S. Rozelle, J. Zhang, and Z. Li (2015). Impact of urbanization on cultivated land changes in China. Land Use Policy 45, $1-7$.

Ding, C. (2003). Land policy reform in china: assessment and prospects. Land use policy 20(2), $109-120$.

Dixon, P. and M. Rimmer (2005). Mini-USAGE: Reducing Barriers to Entry in Dynamic CGE Modelling. 8th Annual Conference on Global Economic Analysis, Lübeck, Germany, and June.

Dixon, P. B., B. R. Parmenter, A. Powell, and P. J. Wilcoxen (1992). Notes and Problems in Applied General Equilibrium Analysis. Elsevier Science Publishing Company.

Domeij, D. and M. Floden (2006). The labor-supply elasticity and borrowing constraints: Why estimates are biased. Review of Economic dynamics 9(2), 242-262.

FAO (2017). Faostat. Available from http://faostat3.fao.org/home/E [Accessed: 27 March, 2017].

Fazal, S. (2001). The need for preserving farmland: A case study from a predominantly agrarian economy (India). Landscape and Urban Planning 55(1), 1-13.

Firman, T. (2000). Rural to urban land conversion in Indonesia during boom and bust periods. Land Use Policy 17(1), 13-20.

Friedman, J. and J. Levinsohn (2002). The distributional impacts of indonesia's financial crisis on household welfare: A rapid response methodology. The World Bank Economic Review 16(3), $397-423$.

Fujita, K., F. Mieno, and I. Okamoto (2009). The economic transition in Myanmar after 1988: Market economy versus state control, Volume 1. NUS Press.

Fulton, M. E. and T. Reynolds (2015). The Political Economy of Food Price Volatility: The Case of Vietnam and Rice. American Journal of Agricultural Economics 97(4), 1206-1226.

Gabriel, A. and M. Daniel (2014). New estimates of the elasticity of substitution of land for capital. Manuscript, European Regional Science Association.

General Statistic Office (2011). Statistical Yearbook of Vietnam 2010. Hanoi: Hanoi: Statistical Publishing House.

General Statistic Office (2016a). International Mechandise Trade Vietnam 2014. Hanoi: Hanoi: Statistical Publishing House.

General Statistic Office (2016b). Statistical Yearbook of Vietnam 2015. Hanoi: Hanoi: Statistical Publishing House. 
Gibson, J., G. Boe-Gibson, and G. Stichbury (2015). Urban land expansion in india 1992-2012. Food Policy 56, 100-113.

Giesecke, J. A., N. H. Tran, E. L. Corong, and S. Jaffee (2013). Rice land designation policy in Vietnam and the implications of policy reform for food security and economic welfare. The Journal of Development Studies 49(9), 1202-1218.

Gini, C. (1921). Measurement of inequality of incomes. The Economic Journal 31(121), 124-126.

Godfray, H. C. J., J. R. Beddington, I. R. Crute, L. Haddad, D. Lawrence, J. F. Muir, J. Pretty, S. Robinson, S. M. Thomas, and C. Toulmin (2010). Food security: the challenge of feeding 9 billion people. Science 327(5967), 812-818.

GRiSP (2013). Rice Almanac, 4th edition. Global Rice Science Partnership (GRiSP). Los Banos (Philippines): International Rice Research Institute.

Ha, P. V., H. T. M. Nguyen, T. Kompas, T. N. Che, and B. Trinh (2015). Rice production, trade and the poor: regional effects of rice export policy on households in Vietnam. Journal of Agricultural Economics 66(2), 280-307.

Halimova, N. (2007). The cotton sector in Tajikistan: From macroeconomic impact to social and environmental consequences. The cotton sector in central Asia. In D. Kandiyoti (Ed.), Economic Policy and Development Challenges. School of Oriental \& African Studies University of London.

Ho, S. P. and G. C. Lin (2004). Converting land to nonagricultural use in China's coastal provinces evidence from Jiangsu. Modern China 30(1), 81-112.

Hoang, H. and W. Meyers (2015). Rice demand in vietnam: Dietary changes and implications for policy. Manuscript, Southern Agricultural Economics Association.

Hoang, T. (2015). Estimating the constant elasticity of substitution function of rice production: the case of vietnam in 2012. Master research essay, The Australian National University: Canberra.

IMF (2017). International financial statistics. International Monetary Fund: Washinton D.C. Available from http://www.imf .org/en/data [Accessed: 8 April, 2017].

IRRI (2016). World rice statistics. Available from http://ricestat.irri.org:8080/wrs2/ entrypoint.htm [Accessed: 27 March, 2016].

Ivanic, M. and W. Martin (2008). Implications of higher global food prices for poverty in low-income countries. Agricultural economics 39, 405-416.

Kerkvliet, B. J. (1997). Land struggles and land regimes in the Philippines and Vietnam during the twentieth century. CASA, Centre for Asian Studies Amsterdam.

Khiem, N. and P. Pingali (1995). Supply responses of rice and three food crops in vietnam. In G. Denning and V.-T. Xuan (Eds.), Vietnam and IRRI: A Partnership in Rice Research, pp. 275-290. International Rice Research Institute, Philippines and Ministry of Agriculture and Food Industry, Hanoi, Vietnam. 
Kompas, T., N. T. Che, H. T. M. Nguyen, and H. Q. Nguyen (2012). Productivity, net returns and efficiency: Land and market reform in vietnamese rice production. Land Economics 88(3), 478-495.

Kompas, T., H. T. M. Nguyen, and P. Van Ha (2015). Food and biosecurity: livestock production and towards a world free of foot-and-mouth disease. Food Security 7(2), 291-302.

Kong, X. (2014). China must protect high-quality arable land. Nature 506, 7.

Kurosaki, T. (2008). Crop choice, farm income, and political control in Myanmar. Journal of the Asia Pacific Economy 13(2), 180-203.

Kutzman, D. C. (2016). This land is your land: Property rights and land use in mexico and vietnam. PhD thesis, University of California, Berkeley.

Le, C. Q. (2008). An empirical study of food demand in vietnam. ASEAN Economic Bulletin 25(3), $283-292$.

Lichtenberg, E. and C. Ding (2008). Assessing farmland protection policy in china. Land Use Policy 25(1), 59-68.

Mao, Y., N. Zhao, and X. Yang (2012). Food security and farm land protection in China, Volume 2. World Scientific.

Markussen, T. and F. Tarp (2014). Political connections and land-related investment in rural vietnam. Journal of Development Economics 110, 291 - 302. Land and Property Rights.

Markussen, T., F. Tarp, and K. Van den Broeck (2011). The forgotten property rights: Evidence on land use rights in Vietnam. World Development 39(5), 839-850.

Martini, R. and S. Kimura (2009). Evaluation of agricultural policy reforms in Japan. OECD.

Minot, N. and F. Goletti (1998). Export liberalization and household welfare: the case of rice in vietnam. American Journal of Agricultural Economics 80(4), 738-749.

Minot, N. and F. Goletti (2000). Rice market liberalization and poverty in Viet Nam. International Food Policy Research Institute.

MOF (2015). Decision 1940-qd-btc of the minister of finance on the depreciation of capital goods.

Montgomery, M. R., R. Stren, B. Cohen, and H. E. Reed (2003). Cities Transformed: Demographic Change and Its Implications in the Developing World. Washington D.C.: National Academies Press.

Nelson, A. C. (1990). Economic critique of US prime farmland preservation policies: Towards state policies that influence productive, consumptive, and speculative value components of the farmland market to prevent urban sprawl and foster agricultural production in the United States. Journal of Rural Studies 6(2), 119-142. 
Nielsen, C. P. (2003). Vietnam's rice policy: Recent reforms and future opportunities. Asian economic journal 17(1), 1-26.

Pandey, B. and K. C. Seto (2015). Urbanization and agricultural land loss in india: Comparing satellite estimates with census data. Journal of environmental management 148, 53-66.

Pham, H. and T. Nguyen (2013). Foreign direct investment, exports and real exchange rate linkages in vietnam: Evidence from a co-integration approach. Journal of Southeast Asian Economies 30, $250-262$.

Pingali, P. L. and V.-T. Xuan (1992). Vietnam: Decollectivization and rice productivity growth. Economic development and cultural change 40(4), 697-718.

Ravallion, M. and D. Van de Walle (2008). Land in transition: Reform and poverty in rural Vietnam. World Bank Publications.

Rutten, M., M. van Dijk, W. van Rooij, and H. Hilderink (2014). Land use dynamics, climate change, and food security in vietnam: A global-to-local modeling approach. World Development 59, 29-46.

Schmidhuber, J. and F. N. Tubiello (2007). Global food security under climate change. Proceedings of the National Academy of Sciences 104(50), 19703-19708.

Shoichi Ito, E. Wesley F. Peterson, W. R. G. (1989). Rice in asia: Is it becoming an inferior good? American Journal of Agricultural Economics 71(1), 32-42.

Slayton, T. (2009). Rice Crisis Frensics: How Asian Governments Careflessly Set the World Rice Market on Fire. CGD working paper, Center for Global Development, Whashington DC.

Tan, R., V. Beckmann, L. van den Berg, and F. Qu (2009). Governing farmland conversion: Comparing China with the Netherlands and Germany. Land Use Policy 26(4), 961-974.

Tien, T. D., N. P. Le, and S. P. Marsh (2006). Agricultural land use flexibility in vietnam. In S. P. Marsh, T. MacAulay, and P. Hung (Eds.), Agricultural development and land policy in Vietnam, pp. 41-68. Australian Centre for International Agricultural Research (ACIAR).

Timmer, C. (2010). Reflections on food crises past. Food Policy 35(1), 1-11.

Valero-Gil, J. N. and M. Valero (2008). The effects of rising food prices on poverty in Mexico. Agricultural Economics 39(s1), 485-496.

VOV (2013). Why do farmers abandon rice field? (in Vietnamese: Tai sao nong dan bo ruong?). Interview of Mr. Tang Minh Loc, Director of Cooperative Department of The Ministry of Agricultural and Rural Development on 15/08/2013. Available at http://vov.vn/kinh-te/ vi-sao-nong-dan-bo-ruong-274215.vov [Accessed: 16-Mar-2016].

Vu, L. and P. Glewwe (2011). Impacts of rising food prices on poverty and welfare in Vietnam. Journal of Agricultural and Resource Economics 36(1), 14. 
Vu, L. H. (2008). Essays on the economics of food production and consumption in vietnam. PhD thesis, the University of Minnesota.

Wing, S. (2004). Computable general equilibrium models and their use in economy-wide policy analysis. MIT Joint Program on the Science and Policy of Global Change 6, MIT.

World Bank (2008). Capital matters. Joint Donor Report to the Vietnam Consultative Group Meeting. Hanoi: World Bank. 


\section{Appendix A: Equations in the GE framework}

The main conditions of our GE framework have been described in the Methodology section. Here, we provide only details on other conditions which are standard in GE models (e.g., see Dixon et al., 1992). Specifically, producers in our GE framework minimize their costs so that their input demands are derived by minimising the level of inputs required to produce a certain amount of quantity, as a function of output prices and production quantities, or:

$$
\left.\left[Q_{t}^{i}, F_{t}^{i}\right]=\operatorname{argmin}\left\{\left[w_{t}^{Q}\right]^{\prime} Q_{t}^{i}+\left[w_{t}^{F^{i}}\right]^{\prime} F_{t}^{i}\right]\right\} \quad \text { subject to } f^{i}\left(Q_{t}^{i}, F_{t}^{i}\right)=q_{t}^{i}
$$

where $i \in\{$ rice,non-rice, others $\}, Q_{t}^{i} \equiv\left[Q_{t}^{i, \text { Rice }}, Q_{t}^{i, \text { Non-rice }}, Q_{t}^{i, \text { Others }}, Q_{t}^{i, i m}\right]^{\prime}$ and $F_{t}^{i} \equiv$ $\left[K_{t}^{i}, N_{t}^{i}, L_{t}^{i}\right]^{\prime}$ are quantities demanded for intermediate commodities, imports, and primary factors; $w_{t}^{Q} \equiv\left[w_{t}^{\text {Rice }}, w_{t}^{\text {NonRice }}, w_{t}^{\text {Others }}, w_{t}^{i m}\right]^{\prime}$ and $w_{t}^{F^{i}} \equiv\left[w_{t}^{K}, w_{t}^{N}, w_{t}^{L^{i}}\right]^{\prime}$ are prices; and $q_{t}^{i}$ and $f^{i}$ are the production (supply) quantity and function for industry $i$, respectively.

Producers in our model use a Constant Elasticity of Substitution (CES) technology so that their production function is of the form:

$$
q_{t}^{i} \equiv f^{i}\left(Q_{t}^{i}, F_{t}^{i}\right)=A^{i}\left(\left[\alpha^{i}\right]^{\prime}\left[Q_{t}^{i}\right]^{\left(\sigma^{i}-1\right) / \sigma^{i}}+\left[\beta^{i}\right]^{\prime}\left[F_{t}^{i}\right]^{\left(\sigma^{i}-1\right) / \sigma^{i}}\right)^{\sigma^{i} /\left(\sigma^{i}-1\right)}
$$

where $i \in\left\{\right.$ rice, non-rice, others\}; parameters $\alpha^{i}$ and $\beta^{i}$ are the $4 \times 1$ and $3 \times 1$ coefficient vectors, respectively, for the inputs; $A^{i}$ is a scalar parameter, representing an industry total factor productivity (TFP) which can be always be normalized such that $\sum \alpha^{i}+\sum \beta^{i}=1$ without the loss of generality; and $\sigma^{i}$ is a scalar CES coefficient.

Households demand goods in a way that maximizes their utility given their budget constraint. We use a double-layered utility function to model the household demand to accomodate the substantial difference in price elasticities and substitutability between rice and non-rice on one hand, and others and imports on the other. Accordingly, the top layer of the household demand is in the form:

$$
\begin{aligned}
& Q_{t}^{H}=\operatorname{argmax}\left[\alpha^{H} v_{1}^{\left(\sigma^{H}-1\right) / \sigma^{H}}+\left(1-\alpha^{H}\right) v_{2}^{\left(\sigma^{H}-1\right) / \sigma^{H}}\right]^{\sigma^{H} /\left(\sigma^{H}-1\right)} \\
& \text { subject to }\left[w_{t}^{Q}\right]^{\prime} Q_{t}^{H}=y_{t}^{H}\left(1-s^{H G}-s^{H S}\right)
\end{aligned}
$$

where $Q_{t}^{H} \equiv\left[Q_{t}^{H, r i c e}, Q_{t}^{H, \text { non-rice }}, Q_{t}^{H, \text { others }}, Q_{t}^{H, i m}\right]^{\prime} ; y_{t}^{H}$ is the household income defined in the Methodology section, while $s^{H G}$ and $s^{H S}$ are respective share parameters of income that households spend on government services and savings; and $\sigma^{H}$ is a CES coefficient parameter 
measuring the substitutability between the necessity and non-necessity composite goods. On the second layer, following Dixon and Rimmer (2005), $v_{1}=\left(Q_{t}^{H, \text { rice }}-h^{\text {rice }} N_{t}\right)^{\beta^{H}}\left(Q_{t}^{H, \text { non-rice }}-\right.$ $\left.h^{\text {non-rice }} N_{t}\right)^{1-\beta^{H}}$ is a composite necessity good with a Stone-Geary utility functional form. This composite good includes rice and non-rice with respective share parameters, $\beta^{H}$ and $1-\beta^{H}$ while $N_{t}$ is the population at $t$. Likewise, $v_{2}=\left(Q_{t}^{H \text {,others }}-h^{\text {others }} N_{t}\right)^{\gamma^{H}}\left(Q_{t}^{H, i m}-\right.$ $\left.h^{i m} N_{t}\right)^{1-\gamma^{H}}$ is a composite non-necessity good which include others and imports with the respective share parameters, $\gamma^{H}$ and $1-\gamma^{H}$.

To model real investment, we use the Solow growth model approach and specify investment as a fixed proportion of real GDP. The rationale behind this approach is twofold. First, total investment in Vietnam has been roughly a fixed proportion of total GDP since the early 2000s (World Bank, 2008; General Statistic Office, 2011, 2016b). Second, although the other two relevant approaches, recursive dynamics and perfect foresight dynamics, would be more appropriate, allowing investment to respond not only to income but also to interest rates and other factors, they need information at a particular point in time as the boundary conditions which are not available in most cases. The most common way to circumvent this problem is to pick a steady state and assume the economy would converge to it after an extended period, generally more than 50 years. In our situation, the practical planning time horizon is ten years, being in line with the planning cycle in Vietnam, which is too short for more elaborate assumptions to hold. We also do not have any reliable information on boundary conditions in the distant future. As a result, the Solow growth model approach best suits our case.

Demand for exports of a domestic commodity $i$ is a function with constant elasticity with respect to the relative price of domestic commodities in terms of imported goods:

$$
Q_{t}^{i, e x}=E^{i}\left(\frac{w_{t}^{i}}{w_{t}^{i m}}\right)^{\varepsilon^{i}}
$$

where $i \in\{$ rice,non-rice, others $\}, E^{i}$ is a price-shift non-negative parameter, and $\varepsilon^{i}$ is a non-positive model-specified elasticity parameter.

At the country level, government revenues come from three sources including household spending on government services, factor income taxes imposed on capital, labor, and three types of land, and sales tax, so that:

$$
y_{t}^{G}=s^{H G} y_{t}^{H}+R^{K} w_{t}^{K} K_{t}+R^{N} w_{t}^{N} K_{t}+\sum_{i}\left\{R^{L^{i}} w_{t}^{L^{i}} L_{t}^{i}+R^{i} w_{t}^{i} q_{t}^{i}\right\}
$$


for $i \in\{$ Rice, Non-rice, Others $\}, y_{t}^{G}$ is the government revenues, and other notations are as defined previously or in the Methodology section. The government uses its revenues to finance its expenditure, which is assumed to remain constant, and provide government transfers to households, which is taken a fixed proportion of government spending.

Appendix B: Demand and Supply Elasticity Estimates

\begin{tabular}{l|ccc|ccc}
\hline \multirow{2}{*}{ Group } & \multicolumn{3}{|c|}{ Demand Elasticity ${ }^{(a)}$} & \multicolumn{3}{c}{ Demand Elasticity ${ }^{(b)}$} \\
& Rice & Non-rice & Others & Rice & Non-rice & Others $^{(c)}$ \\
\hline Ull & -0.80 & -0.75 & -1.11 & & & \\
Rurban & -0.72 & -0.76 & -1.20 & & & \\
\hline Red River Delta & -0.82 & -0.74 & -1.06 & & & \\
Midlands \& Northern Mountains & -0.80 & -0.85 & -1.03 & 0.21 & 0.03 & 0.00 \\
Northern \& Coastal Central & -0.80 & -0.85 & -0.98 & 0.21 & 0.02 & 0.00 \\
Central Highlands & -0.90 & -0.69 & -0.99 & 0.21 & 0.03 & 0.00 \\
South East & -0.81 & -0.70 & -1.19 & 0.09 & 0.00 & 0.00 \\
Mekong River Delta & -0.81 & -0.70 & -1.27 & 0.09 & 0.00 & 0.00 \\
\hline Poorest & -0.81 & -0.70 & -1.34 & 0.09 & 0.01 & 0.00 \\
2nd & -0.89 & -0.91 & -1.02 & & & \\
3rd & -0.89 & -0.91 & -1.02 & & & \\
4th & -0.87 & -0.64 & -1.03 & & & \\
5th & -0.87 & -0.64 & -1.03 & & & \\
6th & -0.84 & -0.77 & -1.06 & & & \\
7th & -0.84 & -0.77 & -1.06 & & & \\
8th & -0.83 & -0.66 & -1.11 & & & \\
9th & -0.83 & -0.66 & -1.11 & & & \\
Richest & -0.82 & -0.70 & -1.21 & & & \\
\hline
\end{tabular}

Notes: Household supply elasticities of different land types and capital are assumed to be zero; labour supply elasticities are 0.46 (Domeij and Floden, 2006).

${ }^{(a)}$ : Vu (2008). Estimates for others are the average of nine major food groups including pork, poultry, other meat, fish, vegetables, fruits, other food items, drinks and eating out, weighted by their shares in the household food expenditure;

${ }^{(b)}$ : Khiem and Pingali (1995). Estimates for non-rice are the average of those for maize, cassava and sweet potatoes, weighted by their regional share in the total planted land.

${ }^{(c)}$ : Our assumption. 